\title{
ТРАДИЦИОНАЛИЗМ СЕМЕЙНОГО УКЛАДА И ВОЗРАСТНЫЕ ХАРАКТЕРИСТИКИ БРАЧНОСТИ: О ЧЕМ ГОВОРИТ ПРИМЕР КАРАЧАЕВО-ЧЕРКЕСИИ?
}

\author{
КОНСТАНТИН КАЗЕНИН
}

\begin{abstract}
В статье исследуется связь между характеристиками семейного уклада и возрастными параметрами брачности. Исследование проведено для одного из регионов Северного Кавказа Карачаево-Черкесской Республики (КЧР) и основано на состоявшемся там в 2018 г. опросе женшин репродуктивного возраста. В сопоставительных целях рассматриваются также результатьы аналогичного опроса, проведенного в 2019 году в Ингушетии. Показано, что в данном регионе на сегодня достаточно ярко выражены некоторые характеристики традиционного семейного уклада, закрепляющие авторитет старшего поколения у младшего и ограничивающие роль женщины воспитанием детей и домашней работой. С этими атрибутами семейного «традиционализма» 8 современной демографии связывают определенные особенности брачно-репродуктивного поведения, включая ранний возраст вступления женщины в брак. Анализ результатов опроса, однако, показывает, что такая связь не носит обязательного характера. Основной результат анализа, проведенного с использованием моделей пропорциональных рисков и логистических моделей, состоит в том, что статистически значимая тенденция к более позднему вступлению женщин в брак обнаруживается именно у того этноса КЧР, у которого на сегодня в большей степени сохранень нормы традиционного уклада. Такое усложнение имеющихся представлений о связи семейного «традиционализма» с возрастными характеристиками брачности, как отмечается в статье, имеет важные следствия для анализа демографических трансформачий, происходящих сегодня в различных обществах на фоне ломки традицинного семейного уклада.
\end{abstract}

Ключевые слова: Северный Кавказ, брачность, возраст при вступлении в брак, традиционная семья, гендерные асимметрии.

\section{1. ВВЕДЕНИЕ}

Проблематика, которой посвящена настоящая статья, - связь между характеристиками семейного уклада и возрастными параметрами демографических событий. Мы фокусируемся на тех характеристиках семейного уклада, которые обычно объединяют под термином «традиционная семья», понимая под этим в первую очередь действие в семье норм, закрепляющих авторитет старшего поколения у младшего и ограничивающих роль женщины воспитанием детей и домашней работой. Распространенное среди исследователей представление состоит в том, что чем «традиционнее» в указанном смысле семейный уклад в некотором обществе, тем ниже там возраст вступления женщины в брак, возраст при рождении первого ребенка и т. д. Это представление подтверждается данными многочисленных стран, преимущественно за пределами Западной Европы и Северной Америки (см. раздел 3).

КОНСТАНТИН ИГОРЕВИЧ КАЗЕНИН (kz@ranepa.ru), РОССИЙСКАЯ АКАДЕМИЯ НАРОДНОГО ХОЗЯЙСТВА И ГОСУДАРСТВЕННОЙ СЛУЖБЫ ПРИ ПРЕЗИДЕНТЕ РОССИЙСКОЙ ФЕДЕРАЦИИ, РОССИЯ.

СТАТЬЯ ПОСТУПИЛА В РЕДАКЦИЮ В АПРЕЛЕ 2019 Г. 
На основе данных количественного полевого исследования, проведенного в одном из регионов Северного Кавказа (Карачаево-Черкесии - КЧР), в статье показано, что такая закономерность, однако, не носит обязательного характера. Мы сосредоточиваемся на влиянии «традиционализма» семейного уклада на возраст вступления женщины в брак. Анализ показывает, что ситуация в исследуемом нами регионе во многом противоположна имеющимся типовым ожиданиям: коренные народы Карачаево-Черкесии отличаются по возрастным моделям брачности, но более старший возраст вступления женщины в брак характерен как раз для того этноса, у которого на сегодня в большей степени сохранены нормы традиционного уклада (у карачаевцев). Сохранность норм традиционной семьи предполагает следование определенным возрастным стандартам брачности, но эти стандарты могут быть разными у разных народов даже в рамках одного региона и не обязательно предполагают ранний возраст вступления женщины в брак. Такое усложнение имеющихся представлений о связи семейного «традиционализма» с возрастными характеристиками брачно-репродуктивного поведения имеет важные следствия для анализа демографических трансформаций, происходящих сегодня в различных обществах на фоне ломки традиционного семейного уклада.

Статья построена следующим образом. В разделе 2 кратко представлено понятие традиционных семейных норм, которыми мы оперируем в ходе исследования. В разделе 3 рассматриваются имеющиеся на сегодня представления о связи традиционных семейных норм с параметрами брачно-репродуктивного поведения. Раздел 4 посвящен общим демографическим характеристикам Карачаево-Черкесии. В разделе 5 характеризуется количественный опрос, легший в основу нашего исследования, и приводятся некоторые его дескриптивные результаты. Раздел 6 посвящен статистическому анализу факторов, влияющих на возраст вступления женщины в брак (на основе данных опроса). В разделе 7 обсуждаются результаты проведенного анализа.

\section{2. ТРАДИЦИОННЫЙ СЕМЕЙНЫЙ УКЛАД: ПОНЯТИЕ И СПОСОБЫ ИЗМЕРЕНИЯ}

Понятие традиционного семейного уклада, которым мы оперируем в данной работе, связано с концептуальным аппаратом, который был разработан основоположником различения современного и традиционного общества, немецким социологом Ф. Тённисом, противопоставлявшим Gemeinschaft как общину или общность и Gesellschaft как общество современного типа (Тённис 2002). Среди базовых признаков Gemeinschaft, по Тённису, действие в семье жестких гендерных и поколенческих асимметрий, а также большая зависимость индивида от рода, общины. Это может реализовываться в строгом разграничении функциональных ролей супругов в семье, в зависимости молодежи от старших родственников при принятии важных жизненных решений, тесных связях между родственниками в рамках "большой семьи".

В многочисленных работах показано, что перечисленные характеристики Gemeinschaft в значительной мере свойственны сегодняшнему Северному Кавказу (Павлова 2012; 2013; Сабанчиева 2016; Molodikova, Watt 2014). Необходимо при этом отметить, что имеющиеся исследования также выявляют заметные различия между разными 
северокавказскими территориями и этносами по степени сохранности традиционного уклада семьи, по тому, в какой мере он подвергся эрозии из-за социальных трансформаций советского и постсоветского времени; см., например, (Карпов 2001) о таких различиях по положению и социальной роли женщины; (Стародубровская 2019) о трансформации системы поколенческих и гендерных отношений в некоторых северокавказских сообществах. Исследователи в целом солидарны в том, что изменения, проходившие на Северном Кавказе в последней трети XX - начале XXI века, прежде всего - массовый переезд местного населения в города, во многом затронули и семейный уклад, в той или иной степени вызвали его «модернизацию». Однако к нивелированию различий между Северным Кавказом и большинством других частей России это все же не привело. Поэтому вопрос о влиянии традиционного семейного уклада на демографическое поведение населения, включая матримониальное поведение, для современного Северного Кавказа сохраняет актуальность.

В литературе предлагается большое количество параметров, по которым может быть оценена степень жесткости гендерных и поколенческих иерархий в некотором обществе. Различные параметры, относящиеся к действию гендерных иерархий, получают систематическое рассмотрение в (Mason 1987; Morgan et al. 2002; Agarwala, Lynch 2006). Практически все обсуждаемые там параметры касаются ограничений, накладываемых на роль женщины в семье и на свободу женщины принимать те или иные решения. Очевидно, что при исследовании любого конкретного общества какие-то из предлагаемых параметров могут быть более, а какие-то - менее применимы. Некоторые из обсуждаемых в указанных работах параметров, релевантных для других регионов мира, вряд ли актуальны для сегодняшних реалий Северного Кавказа (как, например, максимальная дальность однодневной поездки, которую женщина может совершить в одиночку, - такие жесткие ограничения, согласно нашим полевым наблюдениям, для сегодняшнего Северного Кавказа в основном не характерны). С другой стороны, большое количество предлагаемых в литературе параметров касается различных сторон отношений внутри супружеской пары, прежде всего - возможности для жены предпринимать различные действия без одобрения мужа (от крупных покупок до посещений своих родственников). Наш опыт полевых исследований показывает, что согласие женщин-респондентов отвечать на вопросы о разных аспектах их отношения с супругом во многих северокавказских сообществах маловероятно. В силу этого мы ограничили исследование гендерных асимметрий наиболее «объективными» параметрами, касающимися тех сторон жизни женщины, которые видны окружающим и для сообщения о которых интервьюеру, как можно ожидать, у женщины не будет препятствий. А именно, для исследования гендерных асимметрий в рамках количественного опроса женщин мы используем следующие параметры:

- факт получения женщиной образования сверх уровня, требуемого законом;

- факт трудовой деятельности женщины за пределами домохозяйства;

- наличие вклада женщины в общий доход семьи.

Эти параметры показывают, закреплена ли за женщиной в семье исключительно роль жены и матери и в какой мере женщина имеет возможность выхода за рамки этой роли. Что касается поколенческих асимметрий, то параметры, с помощью которых они могут быть обнаружены, касаются свободы молодого поколения принимать те или иные 
жизненные решения независимо от мнения старших родственников. Мы используем три группы таких параметров.

Во-первых, это параметры, отражающие роль старших родственников женщины при ее вступлении в брак. Заключение брака по инициативе и при активной организующей роли старших родственников жениха и невесты (arranged marriage) рассматривается в литературе как одно из проявлений поколенческих асимметрий в семейных отношениях и в целом как важный компонент семейного «традиционализма» (Ahearn 2001: 76, Collier 1997). При этом антропологические исследования в разных регионах мира показали, что фактическая роль старших родственников при заключении брака может быть разной, и бинарное противопоставление брака, организованного старшими родственниками, и брака, заключенного будущими супругами без участия старших, не является адекватным (Hart 2007). С учетом этого, а также опираясь на результаты наших качественных полевых исследований (глубинных полуструктурированных интервью) среди жителей Северного Кавказа, мы рассматриваем следующие параметры, касающиеся роли старших родственников при заключении брака: 1) знакомство будущих супругов по инициативе старших родственников или независимо от них; 2) заключение брака по совету старших родственников или по собственной инициативе будущих супругов (учитывая вариативность реально засвидетельствованных на Северном Кавказе «сценариев» заключения брака, допускается и «промежуточная» альтернатива, которой соответствует вариант ответа «решение о браке приняли сами, но по совету старших родственников»); 3) наличие среди родителей супруги односельчан родителей супруга. Все перечисленные параметры, разумеется, определяются только для женщин, состоящих или состоявших в браке (если женщина вступала в брак более одного раза, вопросы в анкете нашего исследования касались ее первого брака).

Во-вторых, для оценки действенности межпоколенческих асимметрий в семье женщины мы используем параметры, характеризующие возможность для женщины принимать различные жизненные решения, не получив одобрения старших родственников. К таким решениям относятся решение о поступлении на работу или учебу и о смене работы, решение о переезде на постоянное или временное жительство в другой регион, решение о смене места жительства в рамках одного и того же населенного пункта и некоторые другие. По предварительной оценке, по таким признакам на сегодняшнем Северном Кавказе следует ожидать значительного разнообразия как между регионами, так и между районами, этносами и даже отдельными населенными пунктами внутри регионов (Казенин, Козлов 2017b). Все эти признаки определимы для совершеннолетних женщин независимо от их брачного статуса. Отметим, что в литературе возможность для женщины принимать самостоятельные решения по таким вопросам чаще рассматривается как характеристика ее отношений с супругом, т. е. гендерных асимметрий в семье (Morgan et al. 2002). Выше мы объяснили отказ от использования таких параметров для исследования гендерных асимметрий в нашем исследовании, однако полагаем возможными использовать их для изучения поколенческих асимметрий, концентрируясь на независимости женщины в указанных вопросах не от мужа, а от старших членов семьи.

Наконец, в качестве еще одного «измерителя» поколенческих асимметрий мы используем параметр совместного/раздельного проживания со старшими родственниками. 
Преобладание «расширенной» семьи, включающей несколько поколений взрослых, с проживанием молодых семей совместно с родственниками мужей рассматривается как ключевая особенность «патриархальности» (patriarchy), понятия, активно используемого в одном из направлений современных исследований трансформаций семейного уклада (Kaser 2002; Gruber, Szołtysek 2012; Lerch 2013). Отличие понятия «патриархальности» в данных работах от описанного выше концепта традиционной семьи состоит главным образом в том, что «патриархальность» определяется не столько по системе отношений в семье, сколько по составу домохозяйств. Мы полагаем возможным рассматривать параметры «патриархальности» в ряду с другими используемыми нами характеристиками семейного уклада.

\section{3. «ТРАДИЦИОННОСТЬ》 СЕМЕЙНОГО УКЛАДА И БРАЧНО-РЕПРОДУКТИВНОЕ ПОВЕДЕНИЕ}

Имеющиеся исследования взаимосвязи признаков семейного уклада, характеризующих его как традиционный, и параметров брачно-репродуктивного поведения за пределами Западной Европы и Северной Америки практически «единогласно» приводят к следующему выводу: чем «традиционнее» устройство семьи, тем выше рождаемость и ниже возраст женщины при вступлении в брак и рождении первого ребенка ${ }^{1}$. Так, в (Malhotra, Vannemann, Kisher 1995) показано, что в тех районах Индии, где доступные данные социальной статистики указывают на высокую степень дискриминации женщин, рождаемость выше, чем в других районах страны. Похожие выводы делаются для Албании в работе (Lerch 2013), где рождаемость также исследуется в территориальном «разрезе». В (Morgan et al. 2002) аналогичная связь различных параметров «традиционности» семейного уклада доказывается на примере разных сообществ ЮгоВосточной Азии.

Наряду с уровнем рождаемости, в ряде работ была также продемонстрирована связь возрастных характеристик брачно-репродуктивного поведения, прежде всего возраста женщины при вступлении в брак, со степенью действенности гендерных и поколенческих иерархий в семье женщины. В известном исследовании (Dyson, Moore 1983) показано, что те штаты Индии, где наблюдается более жесткая гендерная дискриминация, характеризуются более молодым возрастом вступления женщин в брак. В (Gruber, Szołtysek

\footnotetext{
${ }^{1}$ Оговорка, касающаяся стран Западной Европы и Северной Америки, связана с хорошо известной в мировой демографии асимметрией, обычно называемой «линией Хайнала» (в неточной русской транскрипции - Хаджнала - см.: Хаджнал 1979) и разделяющей европейские страны по линии СанктПетербург - Триест. Как было первоначально показано в (Hajnal 1965), слева от этой линии исторически преобладали сравнительно поздние браки при высокой доле окончательного безбрачия, а справа - ранние браки при малой распространенности окончательного безбрачия. Два выделенных Дж. Хайналом исторических типа брачности были названы соответственно «западноевропейским» и «восточноевропейским». Существенно, что Хайнал показал большой «возраст» этого противопоставления, его существование еще до масштабных социальных изменений, имевших место в Западной Европе в Новое время. Тем самым для стран Западной Европы, брачная модель которой во многом была воспроизведена и населением западноевропейского происхождения в Северной Америке, поздний возраст вступления женщин в брак можно рассматривать как элемент традиционного семейного уклада. Однако для других континентов такая возможность в литературе практически не рассматривается.
} 
2012) более молодой возраст женщины при вступлении в брак также рассматривается в качестве одного из коррелятов «патриархальности» семейного устройства.

Исследования некоторых постсоветских стран и регионов, осуществленные на основе выборочных опросов, показали, что фактором, «поддерживающим» там рождаемость в первые десятилетия после распада СССР, стал частичный ренессанс семейного «традиционализма», прежде всего более жесткого противопоставления гендерных ролей и/или авторитета старших поколений в семье (см. напр., (Dommaraju, Agadjanian 2008) для некоторых стран Средней Азии). В (Казенин, Козлов 2017а) показано, что ряд признаков «традиционности» семейного уклада, наряду с личной религиозностью женщины, коррелируют с более молодым возрастом матери при рождении первого ребенка в Дагестане.

\section{4. КАРАЧАЕВО-ЧЕРКЕСИЯ: НЕКОТОРЫЕ ДЕМОГРАФИЧЕСКИЕ ХАРАКТЕРИСТИКИ}

Карачаево-Черкесия (КЧР) - республика в западной части Северного Кавказа. Ее население, по данным Росстата на 1 января 2018 г., составило 466305 человек. Доли наиболее многочисленных народов в составе населения республики, по данным Всероссийской переписи населения (ВПН) 2010 г., составили: карачаевцы - 41,0\%, русские 31,6\%, черкесы - 11,9\%, абазины - 7,8\%, ногайцы - 3,3\%. Республика отличается весьма низкой на фоне РФ в целом долей городского населения: на 1 января 2018 г. горожане составляли 42,7\% от всех жителей республики. Как показано в (Белозеров 2005), наиболее заметный рост городского населения в регионе имел место в 1960-е - 1970-е годы, в первую очередь за счет миграции в города сельского населения. Процент городского населения, по данным Всесоюзной переписи населения 1959 г., составлял всего 23,6\%, а по переписи 1979 г. - уже 43,5\%, т. е. был близок к сегодняшнему уровню. Если в 1960-е - 1970-е годы среди мигрантов из села в город преобладало русское население, то затем интенсифицировалась и миграция в города местных этносов, шедшая одновременно с отъездом части русского населения городов в другие регионы (Белозеров 2005: 108-130). Это отразилось на доле «автохтонных» этносов среди жителей столицы республики Черкесска (где на 2018 г. сконцентрирован 61\% всего городского населения республики и $26 \%$ всех жителей региона): по переписным данным, в 1959 г. общая доля в населении города четырех наиболее многочисленных неславянских народов региона (карачаевцев, черкесов, абазин, ногайцев) составила 5,9\%, в $1970-11,9 \%$, в $1979-18,6 \%$, в $1989-24,5 \%$, в $2002-36 \%$, в $2010-39,3 \%$.

Динамика рождаемости в регионе после распада СССР, согласно официальной статистике, в целом повторяла общероссийскую, снижаясь в 1990-е и постепенно восстанавливаясь в 2000-е (рисунок 1). Абсолютное значение коэффициента суммарной рождаемости (КСР) с 1990 по 1999 г. в КЧР превышало общероссийское в среднем на 25\%, позже разница между регионом и страной заметно уменьшилась. Более высокая по сравнению с общероссийской рождаемость в 1990-е может объясняться, в частности, тем, что у неславянских народов региона снижение рождаемости, соответствующее первому демографическому переходу, имело место позже, чем у русских. Как показано на рисунке 2 , 
согласно переписи 2010 г. у карачаевцев, черкесов, абазин и ногайцев в возрастах старше 40-44 лет число рожденных детей на 1000 женщин превышало 2000, в то время как у русского населения региона этот показатель был ниже 2000 во всех возрастных группах младше 70 лет. Рождаемость у неславянских этносов, как видно на рисунке 2, была выше, чем у русских, в том числе и в тех возрастных группах, которые в 1990-е годы находились в репродуктивном возрасте. Однако в возрастных группах младше 30 лет перепись 2010 г. уже не зафиксировала отставания русских от неславянских этносов по накопленной рождаемости: рисунок 2 демонстрирует значительную межэтническую конвергенцию по рождаемости в этих возрастах. То есть отставание КЧР от РФ в целом по рождаемости, начавшееся после 2009 г., шло в условиях, когда этнический состав региона перестал быть фактором, способствующим более высокому по сравнению со страной в целом уровню КСР. Интересно отметить, что высокая доля сельского населения в КЧР также не вела в 2000-2010-е годы к более высокой рождаемости по сравнению с общероссийской. Не вело к ней и увеличение доли неславянских коренных этносов в населении республики, вызванное отъездом русского населения из КЧР².

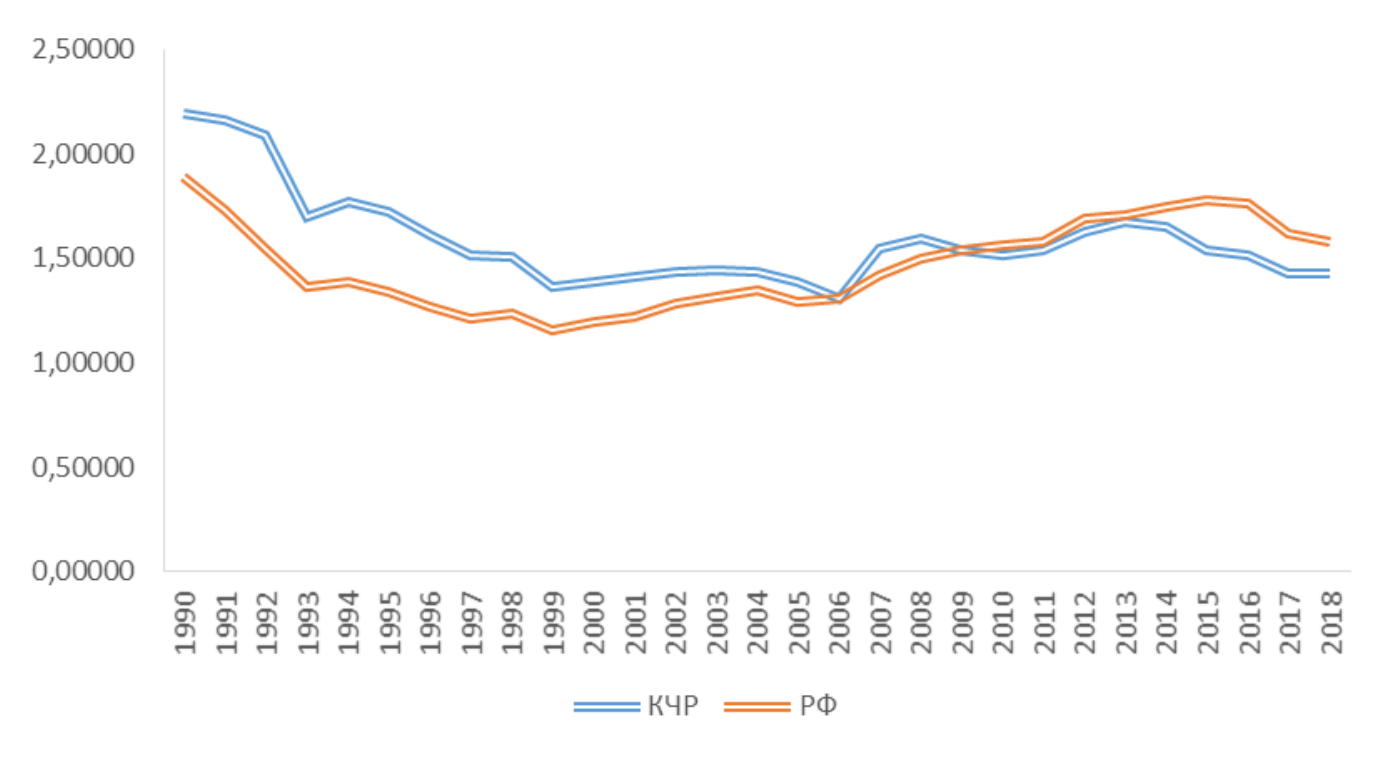

Рисунок 1. Коэффициент суммарной рождаемости, РФ и КЧР, 1990-2018

Источник: Данные Росстата.

\footnotetext{
${ }^{2}$ А.И. Ракша обратил внимание автора на то, что низкие значения КСР по КЧР в 2010-е годы могут быть связаны с завышенными данными по числу женщин в репродуктивных возрастах. О том, что фиксируемая официальными источниками невысокая рождаемость в регионе в этот период может отчасти быть «артефактом» особенностей учета населения, заставляет думать экстраординарно низкое значение КСР по первым детям: согласно Росстату, в 2015 г. данный показатель в КЧР составил всего 0,53, в 2016 - 0,51, в 2017 - 0,48; эти значения почти на треть ниже общероссийских за те же годы. Столь низкий уровень рождаемости первых детей можно было бы объяснить массовым откладыванием первых рождений, но отраженная в данных Росстата динамика среднего возраста матери при рождении первого ребенка в КЧР за 2015-2017 гг. на это не указывает (рисунок 3).
} 


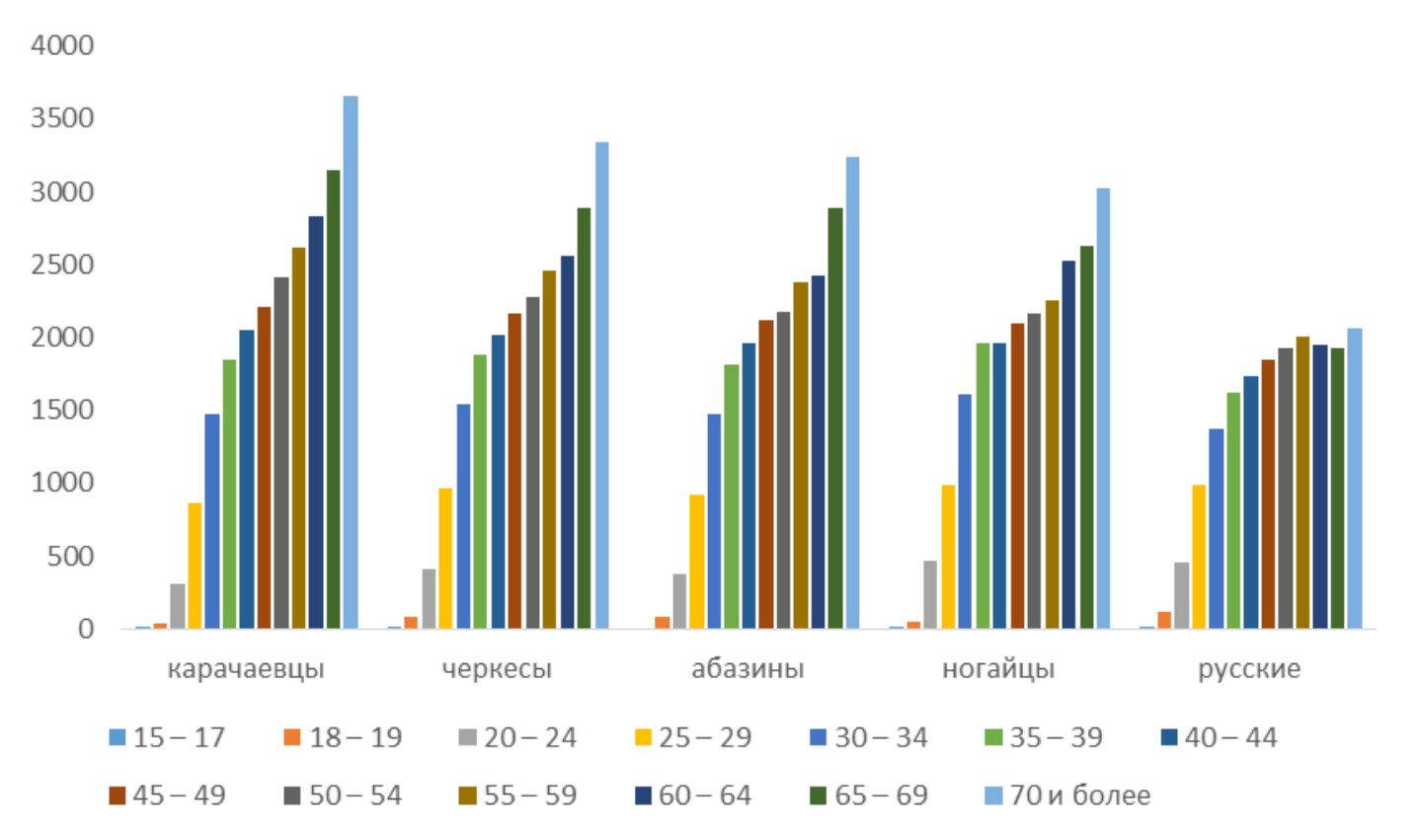

Рисунок 2. Число рожденных детей на 1000 женщин у основных национальностей КЧР по возрастным группам, 2010

Источник: Данные ВПН-2010.

Из возрастных характеристик рождаемости приведем динамику возраста матери при рождении первого ребенка в КЧР по сравнению с общероссийской (рисунок 3; данные по КЧР отсутствуют за 2000-2008 гг., когда в регионе не разрабатывалась статистика по очередности рождений). Возраст «старта» материнства на момент распада СССР в КЧР был несколько выше, чем в РФ в целом, а затем в основном рос, но медленнее общероссийского показателя, и даже несколько отстал от него в последние годы.

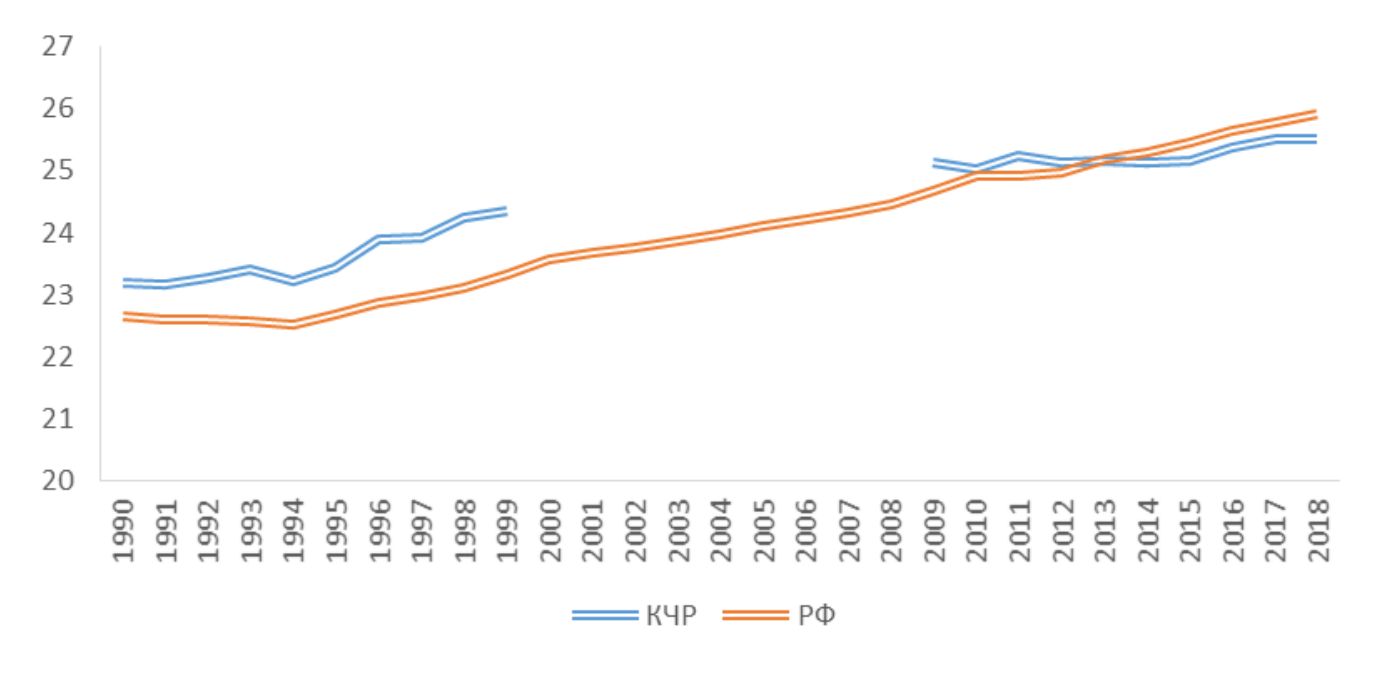

Рисунок 3. Средний возраст матери при рождении первого ребенка, РФ и КЧР, 1990-2018

Источник: Данные Росстата. 


\section{5. КОЛИЧЕСТВЕННОЕ ИССЛЕДОВАНИЕ В КЧР: ХАРАКТЕРИСТИКИ И НЕКОТОРЫЕ ДЕСКРИПТИВНЫЕ РЕЗУЛЬТАТЫ}

Опрос женщин 15-39 лет был проведен в мае-июне 2018 г. во всех городских округах и муниципальных районах Карачаево-Черкесии (в республике имеется два городских округа - Черкесский и Карачаевский - и десять муниципальных районов). Всего было опрошено 756 женщин. Опрос проводили путем обхода домохозяйств местными интервьюерами женского пола, прошедшими необходимый инструктаж, с последующим телефонным контролем.

Число опрошенных в каждом районе или городском округе было пропорционально доле его жителей в общем числе жителей КЧР (в отсутствие официальных данных о текущей половозрастной структуре по муниципальным образованиям руководствоваться долей только женщин включенных в опрос возрастов в их общей численности в КЧР не представлялось возможным). В каждом муниципальном районе населенные пункты были разбиты на две группы по численности в них жителей (условно - «крупные» и «мелкие» села), из каждой такой группы в каждом районе случайным образом для проведения опроса было отобрано по два села. В городских округах было случайным образом отобрано по четыре микрорайона для проведения опроса. В каждом домохозяйстве было опрошено не более одного респондента. Квотирование по возрастным группам внутри общего возрастного диапазона опроса не проводили. Это было связано с уже упомянутым отсутствием актуальных официальных данных по половозрастной и этнической структуре населения по муниципальным образованиям КЧР, которые могли бы послужить основой для такого квотирования. В таблице 1 приведено распределение опрошенных респондентов по пятилетним возрастным группам в сравнении с данными Росстата о доле этих возрастных групп среди всех женщин 15-39 лет в КЧР на 1 января 2017 г. ${ }^{3}$

Таблица 1. Распределение респондентов выборки по возрастным группам

\begin{tabular}{l|c|c|c}
\hline & Число & $\%$ & $\begin{array}{c}\text { Доля данной возрастной группы среди } \\
\text { всех женщин 15-39 лет в КЧР } \\
\text { на 1 января 2017 г. (Росстат), \% }\end{array}$ \\
\hline $15-19$ & 153 & 20,2 & 14,9 \\
$20-24$ & 164 & 21,7 & 16,8 \\
$25-29$ & 161 & 21,3 & 23,6 \\
$30-34$ & 144 & 19,0 & 23,9 \\
$35-39$ & 134 & 17,7 & 20,8 \\
Всего & 756 & 100,0 & 100,0 \\
\hline
\end{tabular}

Как видно, в нашем опросе имел место увеличенный, по сравнению с официальной статистикой, процент молодых возрастов, чему могло быть минимум две причины. Во-первых, «перекос» в сторону молодых возрастов мог возникнуть из-за большой пропорции опрошенных в Черкесске среди всех респондентов нашей выборки (эта большая пропорция была, в свою очередь, обусловлена высокой долей населения Черкесска среди жителей региона, см. выше). В Черкесске выше концентрация молодежи из-за учебы и

\footnotetext{
${ }^{3}$ К сожалению, ряд проблем при фиксации отказов от участия в опросе в ходе исследования не позволяет точно определить число респондентов, не согласившихся на предложение ответить на вопросы анкеты. Можно, однако, говорить о более высоком проценте отказов в городах по сравнению с сельской местностью. Среди городов наиболее высокая частота отказов наблюдалась в Черкесске.
} 
более широких возможностей по трудоустройству по сравнению с сельскими районами и городом Карачаевск. Во-вторых, доля женщин старше 30 лет среди опрошенных могла оказаться меньше по сравнению с официальной статистикой по причине значительной распространенности трудовой миграции женщин этих возрастов за пределы региона.

В распределении опрошенных по национальному составу обращает внимание более высокая доля карачаевок и более низкая доля русских по сравнению с процентом этих народов среди жительниц республики 15-39 лет по данным Всероссийской переписи населения 2010 г. (таблица 2), при том, что доли трех других наиболее многочисленных этносов в выборке довольно точно соответствуют переписным. Отчасти это можно объяснить продолжавшимся после 2010 г. оттоком русского населения, отчасти - большим, по сравнению с официальными источниками, процентом молодых возрастных групп в нашей выборке. По причине того, что у русских в КЧР в последние десятилетия XX века рождаемость была ниже, чем у неславянских народов (см. раздел 4), естественно ожидать, что на сегодня в молодых возрастных группах $(15-19,20-24)$ доля русских будет меньше, чем в более широком возрастном диапазоне. Это наблюдается и в результатах ВПН-2010: среди женщин 15-24 лет доля карачаевок и русских была 44,1 и 26\% соответственно, т. е. у карачаевок в этих возрастах доля была выше, чем среди женщин 15-39 лет, а у русских ниже (доли этих этносов среди женщин 15-39 лет по ВПН-2010 показаны в таблице 2). Следовательно, повышенная по сравнению с переписью доля молодых возрастов в нашей выборке могла способствовать уменьшению в ней доли русского населения.

Таблица 2. Распределение респондентов выборки по национальностям

\begin{tabular}{l|c|c|c}
\hline & Число & $\% *$ & $\begin{array}{c}\text { Доля женщин данной национальности } \\
\text { среди всех женщин 15-39 лет } \\
\text { по ВПН-2010, \% }\end{array}$ \\
\hline Карачаевки & 416 & 56,4 & 42,8 \\
Черкешенки & 84 & 11,4 & 12,5 \\
Абазинки & 65 & 8,8 & 7,8 \\
Русские & 112 & 15,2 & 29,3 \\
Ногайки & 18 & 2,4 & 3,3 \\
Всего & 737 & 100,0 & 95,7 \\
\hline
\end{tabular}

Примечание: *-от указавиих свою национальную принадлежность.

Таким образом, распределение респондентов по возрастным и этническим стратам не полностью соответствовало ожиданиям, формируемым официальной статистикой. Однако различия могут объясняться демографическими процессами, идущими в регионе.

Поскольку выборка квотировалась по муниципальным образованиям, доля респондентов, проживающих в городе на момент опроса, предсказуемо близка текущим данным официальной статистики: 44,5\% против 42,72\% по данным Росстата на 1 января 2018 г. (таблица 3). Интересно при этом отметить, что доля родившихся в городе оказалась почти на 4,8 п.п. выше, чем доля проживающих там на момент опроса, что говорит о малой интенсивности миграции в города среди женщин исследуемых возрастных групп. Такое предположение согласуется с приведенными в разделе 4 данными о том, что пик этой миграции в КЧР приходился на 1960-1970-е годы, т. е. остался в прошлом еще до рождения включенных в опрос респондентов. Наличие «обратной» миграции из города в село, обнаруженной опросом, требует отдельного изучения. Как видно из данных таблицы 3 , 
наибольшее превышение доли родившихся в городе по сравнению с долей проживающих в городе на момент опроса зафиксировано в самой молодой возрастной группе (15-19 лет).

Таблица 3. Распределение респондентов по доле проживающих на момент опроса, родившихся и закончивших учебу в школе в городе, \%

\begin{tabular}{c|c|c|c}
\hline Возрастные группы & $\begin{array}{c}\text { Проживающие в городе } \\
\text { на момент опроса }\end{array}$ & $\begin{array}{c}\text { Родившиеся в городе } \\
\text { Закончившие учебу в } \\
\text { школе в городе }\end{array}$ \\
\hline $15-19$ & 34,6 & 47,7 & 33,1 \\
$20-24$ & 51,2 & 50,3 & 44,5 \\
$25-29$ & 44,4 & 50,6 & 45,4 \\
$30-34$ & 39,6 & 44,4 & 42,1 \\
$35-39$ & 53,0 & 53,8 & 53,8 \\
Всего & 44,5 & 49,3 & 43,7 \\
\hline
\end{tabular}

Таблица 4. Распределение респондентов по брачному статусу на момент опроса, по возрастным группам, \%

\begin{tabular}{c|c|c|c|c}
\hline $\begin{array}{c}\text { Возрастные } \\
\text { группы }\end{array}$ & $\begin{array}{c}\text { Не замужем и } \\
\text { никогда не была }\end{array}$ & Замужем & Разведена & Вдова \\
\hline $15-19$ & 96,7 & 2,6 & 0,7 & 0,0 \\
$20-24$ & 78,0 & 18,9 & 1,2 & 1,8 \\
$25-29$ & 42,2 & 49,7 & 7,5 & 0,6 \\
$30-34$ & 26,4 & 52,1 & 19,4 & 2,1 \\
$35-39$ & 17,9 & 61,9 & 12,7 & 7,5 \\
\hline
\end{tabular}

В таблице 4 проводятся данные о брачном статусе респондентов на момент опроса по возрастным группам, а в таблице 5 - о «накопленной брачности» (доле хотя бы раз вступивших в брак) к моменту опроса и к разным возрастным рубежам. В целом вырисовывается достаточно поздняя возрастная модель брачности. При этом необходимо отметить, что брачная «история» женщины может быть восстановлена по опросу только в довольно сокращенном виде: единственный вопрос, относившийся к возрастным характеристикам брачности, касался возраста вступления в первый брак в полных годах.

Таблица 5. Распределение респондентов по накопленной брачности, по возрастным группам, \%

\begin{tabular}{c|c|c|c}
\hline Возрастные группы & $\begin{array}{c}\text { Доля когда-либо } \\
\text { состоявших в браке к } \\
\text { моменту опроса }\end{array}$ & $\begin{array}{c}\text { Доля вступивших в } \\
\text { первый брак в 22 года } \\
\text { или ранее }\end{array}$ & $\begin{array}{c}\text { Доля вступивших в } \\
\text { первый брак в 25 лет } \\
\text { или ранее }\end{array}$ \\
\hline $15-19$ & 3,3 & - & - \\
$20-24$ & 22,0 & $24,2 *$ & 54,4 \\
$25-29$ & 57,8 & 36,9 & 65,5 \\
$30-34$ & 73,6 & 52,8 & 72,4 \\
$35-39$ & 82,1 & 53,7 & $63,5^{* *}$ \\
Всего & 46,3 & $43,3^{*}$ & - \\
\hline
\end{tabular}

Примечание: *-доля среди достигших 22 лет; **-доля среди достигших 25 лет.

Информацию о возрасте в годах и месяцах при вступлении в брак получить не удалось, что было связано с характерной для КЧР неполной синхронностью заключения религиозного и гражданского брака. Религиозная церемония всегда совершается в дни свадебных торжеств, а регистрация в органах ЗАГС может иметь место через несколько месяцев после них (среди респондентов, вступивших в брак, о том, что их брак был зарегистрирован в органах ЗАГС, сообщил 91\%, но из них лишь 64,4\% сообщили, что регистрация состоялась «в день свадьбы»). В этих условиях респондентки нередко 
затруднялись при определении своего возраста при вступлении в брак с точностью до месяцев. Такая точность требовалась от них при проведении пилотного опроса, по результатам которого было решено ограничиться вопросом о числе полных лет, исполнившихся при вступлении в брак.

Обратимся теперь к ответам на вопросы, касающиеся образования женщины, ее положения на рынке труда и материального положения домохозяйства, к которому она относится (таблица 6). Уровень образования, зафиксированный в выборке, заметно выше, чем отраженный переписью 2010 г. (там доля женщин, имеющих высшее или неоконченное высшее образование, в возрастной группе 20-24 года составила 37\%, 25-29 лет - 33\%, 30-34 года - 25\%, 35-39 лет - 18\%). В связи с таким несоответствием можно сделать два замечания. С одной стороны, наблюдаемый по результатам ВПН-2010 рост доли имеющих высокий уровень образования при переходе от более старших женских поколений к более младшим с большой вероятностью продолжился в прошедшие после переписи годы. Это позволяют предположить наши «качественные» полевые наблюдения, согласно которым в последние 10-15 лет в КЧР все более распространенным становилось представление, что обеспечение учебы девушки в вузе (хотя бы заочной) является одной из обязанностей родителей. В этом смысле превышение уровня образования по данным опроса, проведенного в 2018 г., сравнительно с ВПН-2010 не представляется неожиданным. С другой стороны, такой высокий уровень образования, какой зафиксирован в опросе, все же не выглядит реалистичным. Одна из вероятных причин его возникновения - отмеченные нашими интервьюерами массовые отказы от интервью именно среди женщин, для которых можно предположить низкий уровень образования (домохозяек; проживающих в отдаленных селах и др.). Кроме того, большая доля респондентов, проживающих в Черкесске (определенная квотированием по муниципальным образованиям - см. выше), также могла повысить общий процент респондентов с высоким уровнем образования, поскольку в Черкесске сосредоточено большее количество высших учебных заведений региона, а также учреждений и предприятий, нанимающих на работу лиц с высшим образованием. Таким образом, приходится признать некоторое смещение, имеющееся в нашей выборке, с точки зрения образовательного уровня, которое частично объяснимо особенностями проведения опроса (точно оценить масштабы этого смещения мы не можем, не имея альтернативных текущих оценок образовательного уровня женщин по поколениям; при статистическом анализе, представленном в разделе 6 , проблему смещения частично решали путем обязательного ввода в модели параметра образования в качестве контрольного).

Таблица 6. Доля женщин, которые обучались в высшем учебном заведении, по возрастным группам, \%

\begin{tabular}{c|c}
\hline Возрастные группы & $\begin{array}{c}\text { Обучались в высшем учебном } \\
\text { заведении }\end{array}$ \\
\hline $15-19$ & 21,9 \\
$20-24$ & 67,9 \\
$25-29$ & 77,5 \\
$30-34$ & 74,1 \\
$35-39$ & 66,9 \\
Всего & 61,9 \\
\hline
\end{tabular}




\section{Таблица 7. Сопоставление среднего числа детей у одной женщины по возрастным группам в КЧР по данным ВПН-2010, МП-2015 и по данным опроса на момент ВПН-2010 и МП-2015}

\begin{tabular}{|c|c|c|c|c|}
\hline $\begin{array}{c}\text { Возрастные } \\
\text { группы }\end{array}$ & $\begin{array}{c}\text { Среднее число детей } \\
\text { по данным опроса на } \\
\text { момент ВПН-2010, по } \\
\text { возрасту во время } \\
\text { проведения ВПН- } \\
2010 * \\
\end{array}$ & $\begin{array}{c}\text { Среднее } \\
\text { число детей } \\
\text { по данным } \\
\text { ВПН-2010 }\end{array}$ & $\begin{array}{c}\text { Среднее число детей } \\
\text { по данным опроса на } \\
\text { момент МП-2015, по } \\
\text { возрасту на момент } \\
\text { проведения МП-2015* }\end{array}$ & $\begin{array}{c}\text { Среднее число детей } \\
\text { по данным МП-2015* }\end{array}$ \\
\hline $15-19$ & $0,047(0,000 ; 0,097)$ & 0,037 & $0,023(0,000 ; 0,049)$ & $0,047(0,018 ; 0,075)$ \\
\hline $20-24$ & $0,372(0,274 ; 0,469)$ & 0,373 & $0,313(0,208 ; 0,418)$ & $0,476(0,393 ; 0,559)$ \\
\hline $25-29$ & $0,903(0,736 ; 1,070)$ & 0,919 & $0,927(0,762 ; 1,092)$ & $1,190(1,092 ; 1,289)$ \\
\hline $30-34$ & - & 1,587 & $1,358(1,161 ; 1,556)$ & $1,609(1,489 ; 1,729)$ \\
\hline
\end{tabular}

Примечание: * - среднее и границы доверительных интервалов на 95\%-ном уровне значимости; МПмикроперепись Росстата 2015 г.

Для «внешней» проверки надежности опроса в части оценки демографических показателей мы предприняли сравнения данных по рождаемости по результатам опроса с данными крупнейших опросов населения, проведенных в последнее десятилетие в КЧР: ВПН-2010 и микропереписи Росстата 2015 г. (МП-2015). Для этого на основе данных о годе и месяце рождения каждой опрошенной женщины и каждого ее ребенка было определено число детей у каждой женщины на момент проведения МП-2015 и на момент ВПН-2010, по этим данным была подсчитана средняя накопленная рождаемость для пятилетних возрастных групп по возрасту на момент МП-2015 и ВПН-2010. Затем эти «ретроспективные» опросные показатели были сопоставлены с показателями, подсчитанными для тех же пятилетних групп в КЧР непосредственно по данным МП-2015 и ВПН-2010 (поскольку нашим опросом не были охвачены женщины старше 39 лет на момент опроса, не было возможным сопоставление для возрастов 30-34 и 35-39 на момент ВПН-2010 и для возраста 35-39 на момент МП-2015). Результаты приведены в таблице 7, где значения, подсчитанные по данным МП-2015 и по данным опроса, даны с доверительными интервалами; охват населения ВПН-2010 не требовал использования доверительных интервалов. Как видно из таблицы 7, имеется достаточно точное совпадение среднего числа детей для ВПН-2010, тогда как для момента МП-2015 опрос зафиксировал более низкие уровни рождаемости, чем сама МП-2015. При всей критике надежности результатов ВПН-2010 для Северного Кавказа близость данных этого крупнейшего по охвату обследования населения и данных нашего опроса представляется определенным доводом в пользу адекватности последнего.

Обратимся теперь к распределению среди респондентов тех признаков, которые мы в разделе 2 отнесли к индикаторам традиционного семейного уклада. В таблице 6 мы уже видели возрастное распределение женщин, обучавшихся в высшем учебном заведении. В таблице 8 дано распределение других характеристик, связанных с учебой женщины и ее работой за пределами домохозяйства. Однонаправленную межпоколенческую динамику имеют две характеристики, определенные только для замужних женщин: доля работавших после вступления в брак и доля тех, кто на момент опроса вносил вклад в доход семьи. Повышение этих показателей к более молодым возрастам может свидетельствовать об усилении гендерных асимметрий к младшим поколениям, однако также может быть 
объяснено ухудшением условий на рынке труда, вследствие которого молодые женщины испытывают трудности в поиске работы.

Таблица 8. Доли респондентов, давшие определенные варианты ответов на вопросы об образовании, положении на рынке труда и своем вкладе в доход семьи, по возрастным группам, \%

\begin{tabular}{c|c|c|c|c|c}
\hline $\begin{array}{c}\text { Возрастные } \\
\text { группы }\end{array}$ & $\begin{array}{c}\text { Училась после } \\
\text { окончания } \\
\text { средней школы }\end{array}$ & $\begin{array}{c}\text { Работает на } \\
\text { момент опроса }\end{array}$ & $\begin{array}{c}\text { Училась после } \\
\text { вступления в } \\
\text { брак* }\end{array}$ & $\begin{array}{c}\text { Работала после } \\
\text { вступления в } \\
\text { брак* }\end{array}$ & $\begin{array}{c}\text { Вносит вклад в } \\
\text { доход семьи* }\end{array}$ \\
\hline $15-19$ & 55,5 & 23,1 & 60,0 & 40,0 & - \\
$20-24$ & 91,8 & 64,0 & 37,8 & 57,9 & 14,3 \\
$25-29$ & 95,6 & 78,0 & 45,2 & 61,8 & 30,9 \\
$30-34$ & 93,0 & 76,6 & 48,0 & 65,4 & 35,8 \\
$35-39$ & 88,0 & 81,5 & 39,3 & 67,6 & 42,7 \\
Всего & 85,0 & 64,5 & 43,6 & 64,0 & 33,3 \\
\hline
\end{tabular}

Примечание: *-доля среди состоящих в браке.

В таблице 9 приведено возрастное распределение признаков, которые мы рассматриваем как свидетельства действия в семье женщины поколенческих иерархий. Из таблицы 9 видно, что заключение браков по инициативе старших родственников не является преобладающей практикой, однако по-прежнему достаточно распространено, по крайней мере, на стадии знакомства будущих супругов, причем однонаправленной межпоколенческой динамики не прослеживается.

Таблица 9. Доли респондентов, давших определенные варианты ответов на вопросы, касающиеся поколенческих асимметрий, по возрастным группам, \%

\begin{tabular}{c|c|c|c|c|c}
\hline $\begin{array}{c}\text { Возрастные } \\
\text { группы }\end{array}$ & $\begin{array}{c}\text { Познакомилась } \\
\text { с будущим } \\
\text { супругом без } \\
\text { участия } \\
\text { родственников* }\end{array}$ & $\begin{array}{c}\text { Самостоятельно } \\
\text { приняла } \\
\text { решение о } \\
\text { вступлении в } \\
\text { брак* }\end{array}$ & $\begin{array}{c}\text { Живет } \\
\text { совместно со } \\
\text { старшими } \\
\text { родственниками } \\
\text { мужа }\end{array}$ & $\begin{array}{c}\text { Родители и/или } \\
\text { родители мужа } \\
\text { участвуют в } \\
\text { воспитании } \\
\text { детей** }\end{array}$ & $\begin{array}{c}\text { Считает } \\
\text { важным дать } \\
\text { детям знания о } \\
\text { традициях } \\
\text { своего народа }\end{array}$ \\
\hline $15-19$ & 60,0 & 60,0 & 84,0 & - & 34,0 \\
$20-24$ & 60,5 & 89,2 & 77,2 & 69,6 & 39,0 \\
$25-29$ & 77,4 & 95,7 & 61,0 & 76,1 & 36,2 \\
$30-34$ & 68,3 & 82,5 & 50,3 & 64,1 & 37,6 \\
$35-39$ & 71,0 & 85,0 & 38,9 & 55,3 & 38,1 \\
Всего & 70,6 & 87,2 & 63,2 & 64,4 & 38,1 \\
\hline
\end{tabular}

Примечание: *-доля среди состоящчих в браке; **-доля среди имеющих хотя бы одного ребенка.

Таблица 9 (продолжение)

\begin{tabular}{c|c|c|c}
\hline $\begin{array}{c}\text { Возрастные } \\
\text { группы }\end{array}$ & $\begin{array}{c}\text { Требуется одобрение } \\
\text { старших родственников для } \\
\text { переезда в другой регион }\end{array}$ & $\begin{array}{c}\text { Требуется одобрение } \\
\text { старших родственников для } \\
\text { вступления в брак }\end{array}$ & $\begin{array}{c}\text { Требуется одобрение } \\
\text { старших родственников для } \\
\text { смены места жительства } \\
\text { внутри населенного пункта }\end{array}$ \\
\hline $15-19$ & 90,5 & 69,4 & 88,5 \\
$20-24$ & 83,0 & 60,1 & 79,6 \\
$25-29$ & 75,2 & 54,8 & 72,6 \\
$30-34$ & 69,3 & 56,3 & 65,9 \\
$35-39$ & 72,9 & 56,3 & 64,1 \\
Всего & 78,5 & 59,5 & 74,6 \\
\hline
\end{tabular}

Об участии старших родственников в воспитании детей, а также о совместном проживании со старшими родственниками мужа сообщили более половины респондентов, 
и распространенность обоих этих явлений растет от старших поколений к младшим. Это может быть связано с определенной «ретрадиционализацией» семейного уклада, но может также объясняться тем, что молодые семьи менее «устойчивы» экономически и поэтому в большей степени зависят от старших родственников, а также испытывают значительные трудности с приобретением или арендой отдельного жилья. Что касается зависимости от старших родственников при принятии тех или иных жизненных решений, то она, как видно из таблицы 9, в целом оказалась весьма сильной: о необходимости одобрения старшими родственниками переезда в другой регион, в другой населенный пункт и одобрения ими решения о вступлении в брак или разводе заявили более $50 \%$ респондентов. Более того, виден процентный рост тех, кому требуется такое одобрение, от более старших возрастных групп к более младшим (что опять же можно рассматривать как свидетельство «ретрадиционализации», а можно - как свидетельство позднего «отделения» молодого поколения от родителей и старших родственников, высокого уровня «опеки» со стороны старших вследствие экономической несамостоятельности молодежи, трудностей, с которыми молодежь сталкивается при поиске работы).

\section{Таблица 10. Межэтнические различия респондентов по признакам семейного «традиционализма»}

\begin{tabular}{|c|c|}
\hline Признак & $\begin{array}{c}\text { Различия между карачаевцами и другими этносами } \\
\text { по доле женщин, имеющих положительное значение } \\
\text { этого признака (значимость на 95\%-ном уровне) }\end{array}$ \\
\hline Имеет постоянную работу на момент опроса & Незначимы \\
\hline Жена вносит вклад в доход семьи & Незначимы \\
\hline $\begin{array}{l}\text { Сама решила выйти замуж за нынешнего супруга } \\
\text { (а не вышла замуж по решению родственников) }\end{array}$ & У карачаевцев значимо ниже \\
\hline Сама познакомилась с будущим супругом & У карачаевцев значимо ниже \\
\hline $\begin{array}{l}\text { Среди родителей женщины и ее супруга есть } \\
\text { односельчане }\end{array}$ & Незначимы \\
\hline $\begin{array}{l}\text { Получала профессиональное образование после } \\
\text { вступления в брак }\end{array}$ & Незначимы \\
\hline $\begin{array}{l}\text { Считает важным дать детям знания о традициях } \\
\text { своего народа }\end{array}$ & У карачаевцев значимо выше \\
\hline $\begin{array}{l}\text { Нужно одобрение старших родственников для } \\
\text { вступления в брак или развода }\end{array}$ & У карачаевцев значимо выше \\
\hline $\begin{array}{l}\text { Нужно одобрение старших родственников для } \\
\text { переезда в другой регион }\end{array}$ & У карачаевцев значимо выше \\
\hline $\begin{array}{l}\text { Нужно одобрение старших родственников для } \\
\text { смены места жительства внутри населенного } \\
\text { пункта }\end{array}$ & У карачаевцев значимо выше \\
\hline $\begin{array}{l}\text { Проживает совместно со старшими } \\
\text { родственниками (своими или мужа) }\end{array}$ & У карачаевцев значимо выше \\
\hline
\end{tabular}

Распределение признаков, рассматриваемых нами как индикаторы

«традиционности» семейного уклада, было исследовано не только в разрезе возрастных групп, но и в этническом разрезе. Обнаружилось, что один из этносов региона (карачаевцы) согласно данным опроса заметно отличается от других народов более традиционным семейным укладом. В таблице 10 резюмировано сопоставление респондентов карачаевской национальности и респондентов всех других национальностей по параметрам семейного «традиционализма». Для респондентов карачаевской и других национальностей отдельно вычисляли средние значения приведенных в таблице дихотомических параметров, каждый 
из которых получал значение 1 , если респондент обладал соответствующим признаком, и 0 , если не обладал. Сравнение средних значений большинства этих параметров выявило различия на 95\%-ном уровне значимости, причем во всех таких случаях карачаевцы отличаются в сторону большей «традиционности» ${ }^{4}$. Аналогичное распределение значимых и незначимых различий дало применение непараметрического теста Манна-Уитни (за исключением параметра проживания совместно со старшими родственниками, по которому данный тест оценил межэтнические различия как незначимые; результаты применения теста Манна-Уитни здесь не показаны) ${ }^{5}$.

\section{6. АНАЛИз}

Предпринятый нами анализ фокусирован на возрасте вступления женщины в первый брак. Такой выбор был продиктован следующими соображениями. Во-первых, как отмечалось в разделе 3, молодой возраст вступления в брак в ряде имеющихся исследований признается связанным с признаками традиционного семейного уклада, и представляло интерес проверить эту связь для изучаемого социума. Во-вторых, возраст вступления в брак в случае КЧР определяет характеристики рождаемости в большей степени, чем, например, в сегодняшней России в целом или в странах Западной Европы. Причина в крайне низком уровне внебрачной рождаемости в этом регионе. По данным опроса лишь две респондентки, никогда не состоявшие в браке, имели детей. В таких условиях возраст вступления женщины в брак является определяющим фактором для возраста при рождении первого ребенка, а от этого возраста, в свою очередь, ожидается влияние на уровень рождаемости (Bongaarts 1999). Таким образом, можно предполагать, что возраст вступления в первый брак в случае КЧР будет «корневым» показателем, в значительной мере влияющим на другие характеристики брачно-репродуктивного поведения.

Необходимо при этом оговорить одно важное ограничение, связанное с выбором возраста вступления в первый брак в качестве зависимой переменной при анализе. Как уже упоминалось в разделе 5, по результатам опроса мы располагали информацией только о числе полных лет, исполнившихся женщине при вступлении в первый брак. Это означало огрубление статистического анализа, «шаг» которого мог быть только годовым, но не месячным ${ }^{6}$.

\footnotetext{
${ }^{4}$ Очевидно, что применительно к замужним женщинам такой вывод корректно делать, учитывая национальность не только самой женщины, но и ее мужа. Однако доля межнациональных браков у респондентов карачаевской национальности оказалась всего $11 \%$ (при 24\% по всей выборке). Поэтому не будет большим огрублением считать, что различия между ответами женщин карачаевской и других национальностей отображают различия между карачаевскими и некарачаевскими семьями.

${ }^{5}$ Отметим, что значимые отличия респондентов-карачаевцев от респондентов других национальностей в сторону большего семейного «традиционализма» не могут быть объяснены контрастами между этими группами по городскому/сельскому проживанию, поскольку доли сельских жительниц среди карачаевцев и респондентов других национальностей оказались весьма близки: 54,4 и 56,9\% соответственно.

${ }^{6}$ Одним из следствий того, что в анализ могли быть включены данные по возрасту вступления женщин в первый брак только с точностью до полных лет, стала затрудненность статистического анализа факторов, влияющих на возраст женщины при рождении первого ребенка. Хотя данные об этом возрастном параметре по результатам опроса были доступны с точностью до месяца, не могло быть определено точное число месяцев, прошедших между вступлением в брак и появлением на свет первенца. Это ставило перед
} 
В ходе анализа результатов опроса мы проверяли две гипотезы.

- Гипотеза 1. Признаки традиционализма значимы для возраста вступления в брак.

- Гипотеза 2. Карачаевцы отличаются от других этносов по возрастным характеристикам вступления в брак.

Гипотеза 1 вытекает из тех результатов исследований разных стран и регионов, которые кратко резюмированы в разделе 3. Гипотеза 2 была выдвинута с учетом результатов тех же исследований, а также зафиксированной опросом более высокой «традиционности» карачаевских семей (см. выше). Отметим, что проверка второй гипотезы наиболее очевидным «дескриптивным» методом не подтвердила ее: между средним возрастом вступления в брак респондентов карачаевской и других национальностей различий на 95\%-ном уровне значимости обнаружено не было. Это, однако, могло быть связано с какими-либо другими значимыми для возраста вступления в первый брак признаками, по которым могут различаться респонденты разных национальностей в нашей выборке, поэтому для более надежного результата требовалась проверка Гипотезы 2 путем включения параметра этнической принадлежности в модель наряду с контрольными параметрами.

Были построены два типа моделей: модели пропорциональных рисков (с регрессией Кокса $^{7}$ ), в которых моделируемым событием было вступление женщины в первый брак, и логистические модели для вероятности вступления в брак к разным возрастным отметкам до 25 лет.

В моделях пропорциональных рисков зависимой переменной был риск вступления в брак, определявшийся для всех полных лет, прожитых респондентками в возрасте от 15 лет 0 месяцев (т. е. для 16-го, 17-го и т.д. года жизни). Для женщин, не вступивших в брак, в анализ включали все полные годы до момента опроса; для женщин, вступивших в брак, годы, прожитые после этого события, в анализ не включали (осуществляли так называемое правостороннее цензурирование). Поскольку в анализ включали только полностью прожитые годы, женщин, вступивших в брак во столько же полных лет, сколько им было на момент опроса, из анализа исключали (предшествующий опыт применения модели пропорциональных рисков для анализа демографического поведения населения Северного Кавказа см. в (Митрофанова 2019)).

Во все модели были включены следующие параметры, характеризующие поколенческую принадлежность и социальные характеристики женщины:

выбором: либо анализировать факторы, влияющие на возраст рождения первого ребенка, без учета возраста вступления в брак (однако игнорировать срок проживания в браке для такого анализа некорректно), либо огрублять данные о возрасте при рождении ребенка до полных лет (но, учитывая, что средняя по выборке разность между числом полных лет при рождении первого ребенка и при вступлении в брак меньше 2,5 лет, при таком анализе было бы трудно получить статистически значимые результаты из-за малого числа человеко-лет, которые бы «остались» после правостороннего цензурирования). Возрастные характеристики рождаемости в такой ситуации представляется более корректным исследовать, используя в качестве зависимого параметра не возраст материнства, а число детей к разным возрастным рубежам. Такой анализ будет предпринят в ходе дальнейшей обработки результатов опроса.

7 О применении таких моделей к анализу демографических событий см. (Бурдяк 2007). 
- год рождения женщины (по пятилетним интервалам: 1979-1983, 1984-1988, 1989 1993, 1994-1998, 1999-2003);

- место рождения (город/село);

- наличие высшего или неоконченного высшего образования;

- $\quad$ наличие работы на момент опроса.

Первые два параметра были контрольными. Параметры, связанные с образованием и работой, выше были предложены нами среди индикаторов действия гендерных асимметрий в семье женщины. Однако если другие индикаторы гендерных асимметрий, а также индикаторы поколенческих асимметрий включали в модели выборочно в разных комбинациях, параметры работы и образования были включены (одновременно или по одному) во все модели. Такое решение связано с тем, что образование и занятость женщины известны как факторы, универсально влияющие на рождаемость, при этом ожидаема их корреляция с другими параметрами, выступающими в моделях в качестве независимых (например, для сельских женщин ожидается более низкий уровень образования). Тем самым невключение параметров образования и трудовой деятельности в модели могло бы привести к смещениям.

Необходимо оговорить, что в силу особенностей моделей пропорциональных рисков все включаемые в них независимые параметры либо должны иметь одно значение для всех прожитых женщиной временных интервалов (в нашем случае - человеко-лет), включаемых в анализ, либо специфицироваться отдельно для каждого такого интервала. При этом работа и уровень образования - это признаки, приобретаемые в ходе жизненного пути, и, строго говоря, рассматривать их значение в качестве постоянного на всем интервале от 15 лет до момента опроса или вступления в первый брак некорректно. Однако, учитывая, что более 90\% респондентов, продолжавших образование после окончания школы, начали его получение в возрасте младше 19 лет, можно говорить о том, что факт послешкольного образования - это параметр, единообразно характеризующий почти весь прожитый женщиной репродуктивный период, кроме его самой начальной части. Важно также учитывать, что наличие планов получения образования в ближайшем будущем с большой вероятностью влияет на матримониальное поведение женщины в самом раннем репродуктивном возрасте, снижая вероятность вступления в этом возрасте в брак. Что касается трудовой занятости вне домохозяйства, то ее наличие/отсутствие в разных возрастах с точностью до полных лет установить в ходе опроса не представлялось возможным: пилотный опрос показал, что респондентам затруднительно восстанавливать свою «трудовую биографию» с годовым шагом. Тем самым характеризовать трудовую занятость женщины через ее наличие/отсутствие на момент опроса, видимо, было единственной возможностью.

В рамках проверки Гипотезы 1 в модели пропорциональных рисков, наряду с перечисленными выше параметрами, в разных комбинациях включали следующие параметры, характеризующие «традиционализм» семейного уклада (обоснование использования этих параметров см. в разделе 2):

- признание важности дать детям знания о традициях своего народа;

- необходимость получить одобрение старших родственников для вступления в брак; 
- $\quad$ необходимость получить одобрение старших родственников для переезда в другой регион;

- необходимость получить одобрение старших родственников при смене места жительств в рамках одного населенного пункта;

- проживание совместно со старшими родственниками (своими или мужа) ${ }^{8}$.

Bсе параметры этого списка для рисков вступления в первый брак оказались незначимыми, тем самым опровергая Гипотезу 1 (соответствующие модели не показаны здесь по соображениям объема и могут быть присланы автором по запросу).

Гипотеза 2, напротив, нашла подтверждение в моделях пропорциональных рисков. Соответствующие модели показаны в таблице 11. Необходимо оговорить, что между конкретными моделями, приводимыми ниже, имеются различия по объему выборки, связанные с тем, что по большинству вопросов, заданных в ходе опроса, часть респондентов отказывалась от ответа. Для каждой модели объем выборки был равен числу респондентов, для которых на основе данных ими ответов можно определить все включенные в эту модель параметры. Размер выборки отдельно указывается при каждой модели. Различия по этим размерам не являются препятствием для сопоставления значимости одного и того же параметра в разных моделях.

\section{Таблица 11. Модели пропорциональных рисков для вступления женщины} в первый брак (по данным опроса)

\begin{tabular}{|c|c|c|c|c|c|c|}
\hline $\begin{array}{l}\text { Параметры } \\
\text { Год рождения }\end{array}$ & (1) & (2) & (3) & (4) & (5) & (6) \\
\hline 1979-1983 & 1 & 1 & 1 & 1 & 1 & 1 \\
\hline 1984-1988 & $0,796^{*}$ & 0,814 & 0,849 & 0,863 & 0,814 & 0,823 \\
\hline 1989-1993 & $0,545 * * *$ & $0,551 * * *$ & $0,565 * * *$ & $0,568 * * *$ & $0,560 * * *$ & $0,558 * * *$ \\
\hline 1994-1998 & $0,262 * * *$ & $0,248 * * *$ & $0,263 * * *$ & $0,245 * * *$ & $0,250 * * *$ & $0,231 * * *$ \\
\hline 1999-2003 & $0,087 *$ & $0,094 * *$ & $0,074 * *$ & $0,079 * *$ & $0,061 * * *$ & $0,064 * * *$ \\
\hline Родилась в городе & 0,850 & 0,867 & 0,864 & 0,878 & 0,900 & 0,916 \\
\hline $\begin{array}{l}\text { Имеет высшее или } \\
\text { неоконченное высшее } \\
\text { образование }\end{array}$ & & & $0,621 * * *$ & $0,634 * * *$ & $0,666 * * *$ & $0,685 * * *$ \\
\hline $\begin{array}{l}\text { Работает на момент } \\
\text { опроса }\end{array}$ & & & & & $0,639 * * *$ & $0,633 * * *$ \\
\hline Карачаевка & & $0,731 * * *$ & & $0,748 * * *$ & & $0,729 * * *$ \\
\hline $\mathrm{N}$ & 699 & 699 & 689 & 675 & 672 & 659 \\
\hline -2Log правдоподобия & 3743,962 & 3668,598 & 3703,164 & 3628,954 & 3571,276 & 3497,664 \\
\hline Хи-квадрат модели & $55,971 * * *$ & $64,358 * * *$ & $68,575 * * *$ & $75,957 * * *$ & $78,001 * * *$ & $84,540 * * *$ \\
\hline
\end{tabular}

Примечание: * $p<0,1,{ }^{* *} p<0,05, * * * p<0,001$.

Из моделей в таблице 11 легко видеть, во-первых, что риски вступления в первый брак значимо убывают от более старших когорт к более младшим. Также они с большой значимостью ниже у женщин, обучавшихся в высших учебных заведениях, и у женщин, имевших работу на момент опроса. Параметр места рождения (в городе или в селе) оказался незначим (также незначимы оказались вводившиеся в модели вместо него параметры, указывающие на окончание школы в городе или в селе и на проживание в городе или в селе

\footnotetext{
${ }^{8}$ Из индикаторов традиционного семейного уклада, обсуждаемых в разделе 2, в модели не были включены те, которые определимы только для замужних женщин.
} 
на момент опроса; соответствующие модели не показаны по соображениям объема). Наконец, риски вступления в первый брак у женщин карачаевской национальности с высокой значимостью оказались ниже, чем у респондентов других национальностей.

Значимость параметра этнической принадлежности, обнаруженная в моделях пропорциональных рисков, подтвердилась и в логистических регрессиях, в которых моделируемым событием было вступление в первый брак к 22, 23, 24 годам (для респондентов, достигших соответствующего возраста к моменту опроса). В этих моделях подтвердилось «постарение» модели брачности в регионе в целом (значимо ниже шансы вступить в брак к этим возрастам у более молодых когорт). Также была обнаружена негативная значимость обучения в высшем учебном заведении для вступления в первый брак к этим возрастам. Что касается параметра этнической принадлежности, то у женщин карачаевской национальности шансы вступления в первый брак к этим возрастам были ниже, чем у женщин других национальностей, на 90\%-ном уровне значимости. В таблице 12 показана логистическая модель для факта вступления в брак к 22 годам (в моделях, построенных для 23 и 24 лет, уровни значимости параметров и «знаки» коэффициентов были такими же).

Таблица 12. Логистическая модель для вступления в брак в 22 года или ранее (по данным опроса; только для респондентов, которым к моменту опроса исполнилось 22 года)

\begin{tabular}{|c|c|c|c|}
\hline & Стандартная ошибка & Вальд & $\operatorname{Exp}(B)$ \\
\hline $1979-83$ & & 9,056 & \\
\hline $1984-88$ & 0,278 & 1,430 & 0,717 \\
\hline $1989-93$ & 0,301 & 8,484 & $0,417 * * *$ \\
\hline $1994-98$ & 0,370 & 2,572 & $0,553^{*}$ \\
\hline $\begin{array}{l}\text { Проживает в городе на момент опроса } \\
(1-\text { да, } 0 \text { - нет) }\end{array}$ & 0,266 & 0,409 & 0,844 \\
\hline $\begin{array}{l}\text { Имеет высшее или неоконченное высшее } \\
\text { образование ( } 1 \text { - да, } 0 \text { - нет) }\end{array}$ & 0,232 & 14,825 & $0,409 * * *$ \\
\hline Карачаевка (1 - да, 0 - нет) & 0,223 & 2,657 & $0,695^{*}$ \\
\hline Константа & 0,285 &, 110 & 1,099 \\
\hline
\end{tabular}

Примечание: $N=497, R^{2}$ Найджелкерке $=0,112 ; * p<0,1, * * p<0,05, * * * p<0,001$.

\section{7. ОБСУЖДЕНИЕ РЕЗУЛЬТАТОВ АНАЛИЗА}

Значимое снижение рисков вступления в брак от более старших поколений к более младшим в целом вписывается в общероссийскую тенденцию повышения возраста вступления в первый брак в постсоветские десятилетия (Захаров 2018: 131-149). Однако, учитывая, что ряд поколений, охваченных опросом, на его момент были далеки от «предельных» возрастов вступления в брак, невозможно определить, в какой мере этот результат говорит о повышении возраста первого супружества, а в какой мере - о росте доли окончательного безбрачия.

Негативная значимость для факта вступления в брак уровня образования и наличия у женщины работы вполне согласуется с общеизвестными мировыми тенденциями. В свете исходных положений нашего анализа эта значимость могла бы рассматриваться и как подтверждение влияния на брачность признаков семейного традиционализма. Однако такая 
интерпретация вызывает вопросы на фоне того, что для других параметров традиционного уклада значимой связи с фактом вступления в брак не обнаружено. При этом уровень образования женщины и наличие у нее работы (в отличие, например, от ее права самостоятельно принимать те или иные жизненные решения) могут быть следствием не только уклада семьи, но и таких «внешних» по отношению к семье факторов, как положение на рынке труда, доступность образовательных услуг и др. Что касается отсутствия значимости параметра сельского/городского проживания, то этот достаточно неожиданный результат требует дальнейшего осмысления.

Обратимся теперь к обнаруженной значимости параметра этнической принадлежности. Подтверждение Гипотезы 2 в ходе нашего анализа, наряду с межэтническими различиями, установленными дескриптивными методами в разделе 5 (таблица 10), приводят нас к следующему заключению: у карачаевского этноса в большей степени, чем у других народов, сохранились признаки традиционного семейного уклада, но при этом принадлежность к данному этносу связана с более поздним возрастом вступления в брак 9 . С точки зрения ожиданий, основанных на исследованиях других стран и регионов, которые суммированы в разделе 3, такой результат парадоксален. Однако тенденция к более поздней брачности у женщин карачаевской национальности, на которую указывают результаты нашего моделирования, косвенно подтверждается данными Всероссийской переписи населения 2010 г.

Как известно, этой переписью не собирались данные о возрасте вступления в брак, но собирались данные о возрасте женщины при рождении первого ребенка. На рисунках П1-П7 Приложения сравнивается кумулятивная вероятность «дожития» бездетными к разным возрастам у женщин карачаевской и двух других крупнейших неславянских этносов КЧР (черкесов и абазин) к разным возрастам для когорт по годам рождения по данным ВПН-2010. Легко заметить, что во всех когортах, начиная с когорты 1950-54 годов рождения, для карачаевок был характерен более поздний «старт» материнства (для когорт, доживших до 40 лет к моменту ВПН-2010, можно констатировать и некоторое превышение у карачаевцев окончательной бездетности). То есть можно говорить о межэтническом отличии возрастной модели рождаемости, наблюдаемом из поколения в поколение в течение по крайней мере нескольких десятилетий. Данные ВПН-2010, разумеется, не позволяют ответить на вопрос, с чем связан регулярно более поздний «старт» материнства у карачаевцев: с более старшим возрастом вступления женщин в брак или с откладыванием первых рождений в браке. Тем не менее обнаруженная опросом тенденция к более позднему вступлению в брак у женщин карачаевской национальности на фоне крайне низкого уровня внебрачной рождаемости позволяет предсказать для них и более старший средний возраст при рождении первого ребенка, и это предсказание подтверждается переписными данными. Важно также отметить, что выявленные ВПН-2010 различия

\footnotetext{
${ }^{9}$ Поскольку у включенных в исследование когорт репродуктивный период не закончен, строго говоря, невозможно определить, связан ли это результат с откладыванием женщинами карачаевской национальности вступления в первый брак или с большей распространенностью среди них установки на окончательную бездетность.
} 
обнаружены уже для женщин 1950-х годов рождения, т. е. родившихся и прошедших первичную социализацию еще до начала массового переселения неславянских народов КЧР из села в город (см. раздел 4). Так что данные ВПН-2010 отражают разницу в возрастных характеристиках демографического поведения, восходящих к тому периоду, когда основные неславянские народы КЧР проживали в основном в селе. Тем самым возрастные различия, о которых идет речь, с большой вероятностью говорят о разнице возрастных установок в традиционных моделях демографического поведения этносов. А если так, то нынешняя более поздняя брачность у карачаевцев может быть объяснена именно большей сохранностью у них традиционного семейного уклада, обнаруженной нами по результатам опроса.

Следовательно, вопреки ожиданиям, формируемым имеющимися исследованиями брачности за пределами Западной Европы и Северной Америки, признаки традиционного семейного уклада не обязательно коррелируют с более ранним возрастом женщины при вступлении в брак. На примере КЧР мы увидели в точности обратную картину: у этноса, характеризующегося более традиционным семейным укладом по сравнению с другими этносами региона, обнаружилась более поздняя возрастная модель брачности. Такой результат не противоречит представлениям о традиционном семейном укладе как о такой организации семьи, при которой от каждого следующего поколения требуется воспроизведение определенных «образцов» поведения предков. Однако данный результат заставляет признать, что эти образцы могут быть разными, в том числе они могут предписывать и относительно позднее наступление демографических событий. Если в некотором социуме заметную роль играют нормы традиционного семейного уклада, то в общем случае уместно предполагать именно сам факт следования каким-либо возрастным образцам матримониального поведения, но не конкретные характеристики возраста брачности. А если у разных этносов связь между признаками традиционного семейного уклада и возрастом первого супружества может быть разнонаправленной, не выглядит неожиданным и тот результат, что на выборке, объединяющей все этносы исследуемого нами региона, эти признаки не обнаруживают значимой однонаправленной связи с тем, во сколько лет женщина вступила в брак.

Добавим, что сочетание признаков традиционализма семейного устройства с достаточно поздним возрастом вступления женщин в брак на Северном Кавказе, повидимому, наблюдается не только в Карачаево-Черкесии. Опрос женщин 16-44 лет в Республике Ингушетия, проведенный нами в 2019 г., показал, что в этом регионе средний возраст женщины при вступлении в первый брак для достигших на момент опроса 40 лет был старше 24 лет (опрос был проведен методом телефонных интервью и охватил 800 респондентов). Ингушетия отличается от КЧР значительно более высокой «сохранностью» многих признаков семейного «традиционализма» (в частности, как показал опрос, там значительно выше, чем в КЧР, доля браков, заключенных по инициативе старших родственников жениха и невесты; выше зависимость женщины от старших членов семьи при принятии различных важных жизненных решений и др.). При этом предварительный анализ результатов опроса показал, что среди социокультурных параметров значимо связаны с более молодым возрастом вступления в брак параметры, характеризующие 
личную религиозность женщины, но не параметры, являющиеся индикаторами традиционности семейного уклада.

Вывод нашей работы имеет некоторые следствия для исследований демографических процессов в развивающихся странах. Масштабное повышение во многих из этих стран среднего возраста «старта» материнства, начавшееся в последней трети прошлого столетия (Bongaarts 1999), принято рассматривать как один из компонентов демографической модернизации, отхода от традиционных установок брачнорепродуктивного поведения. Однако в свете полученных результатов необходимо иметь в виду, что само по себе абсолютное значение среднего возраста женщины при наступлении какого-либо демографического события, даже если оно является высоким на фоне других развивающихся стран, не может автоматически рассматриваться как свидетельство модернизации семьи: это значение может также соответствовать возрастным нормам, задаваемым местными традициями.

Вместе с тем открытым остается вопрос о том, чем определяется «направление» связи между семейным традиционализмом и возрастом вступления в брак. Предопределили ли эту «традицию позднего брака» у карачаевцев какие-либо социальные процессы, разворачивавшиеся среди этого народа в период сталинской депортации 1943-1957 гг., или же она восходит к более давним обычаям - ответы на такие вопросы требуют, разумеется, отдельного исследования.

\section{8. ВЫводы}

В статье была рассмотрена взаимосвязь характеристик семейного уклада и возраста женщины при вступлении в первый брак в одном из регионов Северного Кавказа Карачаево-Черкесии. Исследование основывалось на результатах опроса женщин репродуктивного возраста, проведенного нами в КЧР в 2018 г. Опрос показал, что в этом регионе некоторые признаки традиционного уклада семьи, касающиеся гендерных и поколенческих асимметрий, имеют достаточно большое распространение. При этом влияние семейного «традиционализма» на возрастные характеристики брачности оказалось не вполне таким, каким оно ожидается на основе исследований, проведенных в других странах и регионах. Наиболее неожиданный результат состоит в том, что у этноса, характеризуемого более высокой степенью сохранности норм традиционного семейного уклада, обнаруживается статистически значимая тенденция к более позднему вступлению женщин в брак. Из этого следует, что взаимосвязь между нормами семейного уклада и возрастными характеристиками демографических событий может быть более разнообразной, чем это предполагается на основе проводившихся ранее исследований данной проблематики. Данные Северного Кавказа, отличающегося заметной вариативностью моделей брачно-репродуктивного поведения, а также характеристик семейного уклада, могут дать еще много возможностей для исследования взаимосвязей между ними. Применительно к КЧР следующим шагом, по-видимому, должно стать исследование значимости норм семейного уклада для возрастных параметров и уровня рождаемости. 


\section{БЛАГОДАРНОСТИ}

Опрос в Ингушетии, результаты которого обсуждаются в разделе 7, был проведен в рамках НИР РАНХиГС 2019 г. «Анализ возможностей применения онлайн-исследований демографических характеристик сообществ традиционного уклада». Автор благодарит С.В. Захарова, В.А. Козлова, Е.С. Митрофанову, А.И. Ракшу за регулярные обсуждения результатов исследований брачности и рождаемости на Северном Кавказе.

\section{ЛИТЕРАТУРА}

Белозеров С.В. (2005). Этническая карта Северного Кавказа. М.: О.Г.И.

Бурдяк А.Я. (2007). Применение метода «анализа наступления события» (event history analysis) с помощью пакета SPSS. Spero, 6, 189-202.

Захаров С.В. (Ред.) (2018). Население России - 2016 (Двадиать четвертыий ежегодный демографический доклад). М.: Издательский дом ВШЭ.

Казенин К.И., Козлов В.А. (2017а). Особенности брачно-репродуктивного поведения населения в Республике Дагестан: их причины и социально-экономические последствия. Вестник Института экономики РАH, 2, 65-81. URL: https://publications.hse.ru/mirror/pubs/share/folder/ef6j9823c7/direct/206180572

Казенин К.И., Козлов В.А. (2017b). Возраст материнства в Дагестане: значимость этнического фактора в условиях модернизации. Народонаселение, 1, 46-58. URL: https://www.jour.isras.ru/index.php/population/article/view/6521/6410

Карпов Ю.Ю. (2001). Женское пространство в культуре народов Кавказа. СПб.: Петербургское востоковедение.

Митрофанова Е.С. (2019). Переход во взрослую жизнь: сравнение Северного Кавказа с общероссийской картиной. Журнал исследований сочиальной политики, 17(1), 133-141. doi: 10.17323/727-0634-2019-17-1-133-141

Павлова О.С. (2012). Ингушский этнос на современном этапе. Черты социиальнопсихологического портрета. М.: Форум.

Павлова О.С. (2013). Чеченский этнос сегодня: черты сочиильно-психологического портера. М.: Сам Полиграфист.

Сабанчиева Л.Х. (2016). Гендер в сочиально-политических процессах в КабардиноБалкарии (20-е г2. XX в. - начало ХХІ века). Нальчик: КБИГИ.

Стародубровская И.В. (2019). Кризис традиционной северокавказской семьи в постсоветский период и его социальные последствия. Журнал исследований соииальной политики, 17(1), 37-54. doi: 10.17323/727-0634-2019-17-1-39-56

Тённис Ф. (2002) Общность и общество: Основные понятия чистой соичологии. СПб: Владимир Даль.

Хаджнал Дж. (1979). Европейский тип брачности в ретроспективе. Брачность, рождаемость, семья за три века. Сб. статей род ред. А.Г. Вишневского и И.С. Кона. М., Статистика: 14-70.

Agarwala R., Lynch .S.M. (2006). Refining the Measurement of Women's Autonomy: An International Application of a Multi-dimensional Construct. Social Forces, 84(4), 2069-2090. doi: 10.1353/sof.2006.0079 
Ahearn L. (2001). Invitations to love: literacy, love letters, and social change in Nepal. Ann Arbor: University of Michigan Press.

Bongaarts J. (1999). The fertility impact of changes in timing of childbearing in developing world. Population Studies, 53(3), 277-289. doi: 10.1080/00324720308088

Collier J. (1997). From duty to desire: remaking families in a Spanish village. Princeton: University Press.

Dommaraju P., Agadjanian V. (2008). Nuptuality in Soviet and post-Soviet Central Asia. Asian Population Studies, 4(2), 195-213. doi: 10.1080/17441730802247463

Dyson T., Moore M. (1983). On Kinship Structure, Female Autonomy, and Demographic Behaviorin India. Population and Development Review, 9(1), 35-60. doi: 10.2307/1972894

Gruber S., Szołtysek M. (2012). Quantifying Patriarchy: An Explorative Comparison of Two Joint Family Societies. MPIDR Working Paper WP 2012-017, April 2012. URL: https://www.demogr.mpg.de/en/projects_publications/publications_1904/mpidr_working_pa pers/quantifying_patriarchy_an_explorative_comparison_of_two_joint_family_societies_460 4.htm

Hajnal J. (1965). European marriage pattern in historical perspective. In D.V. Glass, D.E.C. Eversley (Eds.), Population in History. London: Arnold.

Hart K. (2007). Love by Arrangement: The Ambiguity of 'Spousal Choice' in a Turkish Village. The Journal of the Royal Anthropological Institute, 13(2), 345-362. doi: 10.1111/j.14679655.2007.00438.x

Kaser K. (2002). Power and inheritance: male domination, property and family in Eastern Europe, 1500-1900. History of the Family, 7, 375-395. doi: 10.1016/S1081-602X(02)00109-4

Lerch M. (2013). Patriarchy and fertility in Albania. Demographic Research, 29, 133-166. doi: 10.4054/DemRes.2013.29.6

Malhotra A., Vannemann R., Kisher S. (1995). Fertility, Dimensions of Patriarchy, and Development in India. Population and Development Review, 21(2), 281-305. doi: $10.2307 / 2137495$

Mason K.O. (1987). The Impact of Women's Social Position on Fertility in Developing Countries. Sociological Forum, 2(4), 718-745. doi: 10.1007/BF01124382

Molodikova I., Watt A. (2014). Growing up in the North Caucasus: society, family, religion and education. London: Routledge.

Morgan S.P., Stash S., Smith K., Mason K.O. (2002). Muslim and Non-Muslim Differences in Female Autonomy and Fertility: Evidence from Asian Countries. Population and Development Review, 28(3), 515-538. doi: 10.1111/j.1728-4457.2002.00515.x 


\title{
FAMILY TRADITIONALISM AND AGE-SPECIFIC NUPTIALITY PATTERNS: WHAT DOES THE EXAMPLE OF KARACHAY-CHERKESSIA POINT TO?
}

\section{KONSTANTIN KAZENIN}

\begin{abstract}
The paper deals with the relation between traditional family norms and women's age at first marriage. The study is based on data from Karachay-Cherkessia, a republic of the North Caucasus (Russia), and uses results of a survey among women of reproductive ages conducted there in 2018. It has been demonstrated that traditional family norms, including those empowering elder generations and limiting women's social role to housework and bringing up children, are rather strong in that region. It is currently assumed that these norms generally correlate with women's younger age at first marriage. However, our analysis of the data from Karachay-Cherkessia, which used proportional hazard models and logistic regressions, does not fit this assumption. Specifically, it turns out that precisely that ethnic group of Karachay-Cherkessia which shows a higher concentration of traditional family norms also demonstrates a statistically significant tendency towards women's older age at first marriage. Thus the relation between traditional family norms and the timing of marriage appears to vary more across different societies than is supposed. The consequences of this result for the study of demographic transformations taking place in different countries and regions together with the breakdown of traditional family norms are discussed.
\end{abstract}

Key words: North Caucasus, nuptiality, age at marriage, traditional family norms, gender asymmetries.

Konstantin Kazenin (kz@ranepa.ru), The Russian Presidential ACADEmy of National Economy ANd Public ADMINISTRATION, RUSSIA.

DATE RECEIVED : APRIL 2019.

\section{REFERENCES}

Agarwala R., Lynch S.M. (2006). Refining the Measurement of Women's Autonomy: An International Application of a Multi-dimensional Construct. Social Forces, 84(4), 2069-2090. doi: $10.1353 /$ sof.2006.0079

Ahearn L. (2001). Invitations to love: literacy, love letters, and social change in Nepal. Ann Arbor: University of Michigan Press.

Belozerov S.V. (2005) Etnicheskaja karta Severnogo Kavkaza [The ethnic map of the North Caucasus]. Moscow: O.G.I. 302 p. (In Russ.)

Bongaarts J. (1999). The fertility impact of changes in timing of childbearing in developing world. Population Studies, 53(3). 277-289. doi: 10.1080/00324720308088

Burdjak A.Ja. (2007). Primenenie metoda "analiza nastuplenija sobytija" s pomoshchju paketa SPSS [Using the event history analysis method in SPSS]. Spero, 6, 189-202 (In Russ.).

Collier J. (1997). From duty to desire: remaking families in a Spanish village. Princeton: University Press.

Dommaraju P., Agadjanian V. (2008). Nuptuality in Soviet and post-Soviet Central Asia. Asian Population Studies, 4(2), 195-213. doi: 10.1080/17441730802247463

Dyson T., Moore M. (1983). On Kinship Structure, Female Autonomy, and Demographic Behaviorin India. Population and Development Review, 9(1), 35-60. doi: 10.2307/1972894 
Gruber S., Szołtysek M. (2012). Quantifying Patriarchy: An Explorative Comparison of Two Joint Family Societies. MPIDR Working Paper WP 2012-017, April 2012. Retrieved from https://www.demogr.mpg.de/en/projects_publications/publications_1904/mpidr_working_pa pers/quantifying_patriarchy_an_explorative_comparison_of_two_joint_family_societies_460 4.htm

Hajnal J. (1965). European marriage pattern in historical perspective. In D.V.Glass, D.E.C.Eversley (Eds.) Population in History. London: Arnold.

Hart K. (2007). Love by Arrangement: The Ambiguity of 'Spousal Choice' in a Turkish Village. The Journal of the Royal Anthropological Institute, 13(2), 345-362. doi.org/10.1111/j.14679655.2007.00438.x

Karpov Ju.Ju. (2001). Zhenskoe prostranstvo v kul'ture narodov Kavkaza [The female sphere in the culture of peoples of the Caucasus]. Saint-Petersburg: Peterburgskoe vostokovedenie. 419 p. (In Russ.)

Kaser K. (2002). Power and inheritance: male domination, property and family in Eastern Europe, 1500-1900. History of the Family. 7, 375-395. doi: 10.1016/S1081-602X(02)00109-4

Kazenin K.I., Kozlov V.A. (2017a). Osobennosti brachno-reproduktivnogo povedenija naselenija v Respublike Dagestan: ikh prichiny i social'no-ekonomicheskie posledstvija [Special characteristics of nuptiality and fertility in Daghestan: their reasons and socialeconomic consequences]. Vestnik Instituta ekonomiki RAN [The Bulletin of the Institute for Economics, Russian Academy of Science], 2, 65-81 (In Russ.).

Kazenin K.I., Kozlov V.A. (2017b). Vozrast materinstva v Dagestane: znachimost' etnicheskogo faktora v uslovijakh modernizacii [Mother's age in Daghestan: the role of ethnicity in the process of globalization]. Narodonaselenie [Population], 1, 46-58 (In Russ.).

Lerch M. (2013). Patriarchy and fertility in Albania. Demographic Research, 29, 133-166. doi: 10.4054/DemRes.2013.29.6

Malhotra A., Vannemann R., Kisher S. (1995). Fertility, Dimensions of Patriarchy, and Development in India. Population and Development Review, 21(2), 281-305. doi: $10.2307 / 2137495$

Mason K. O. (1987). The Impact of Women's Social Position on Fertility in Developing Countries. Sociological Forum, 2(4), 718-745. doi: 10.1007/BF01124382

Mitrofanova E.S. (2019). Entering adult life: North Caucasus in comparison to other regions of Russia. Journal of Social Policy Studies, 17(1), 133-141 (in Russ.). doi: 10.17323/727-06342019-17-1-133-141

Molodikova I., Watt A. (2014). Growing up in the North Caucasus: society, family, religion and education. London: Routledge. 202 p.

Morgan S.P., Stash S., Smith K., Mason K.O. (2002). Muslim and Non-Muslim Differences in Female Autonomy and Fertility: Evidence from Asian Countries. Population and Development Review, 28(3), 515-538. doi.org/10.1111/j.1728-4457.2002.00515.x

Pavlova O.S. (2012). Ingushskij etnos na sovremennom etape. Cherty social'nopsikhologicheskogo portreta [Ingush people today. Social-psychological characteristics]. Moscow: Forum. 384 p. (In Russ.)

Pavlova O.S. (2013). Chechenskij etnos segodnja: cherty social'no-psikhologicheskogo portreta [Chechen people today: social-psychological characteristics]. Moscow: Sam Poligrafist. 588 p. (In Russ.) 
Sabanchieva L.Kh. (2016). Gender v social'no-politicheskikh processakh v Kabardino-Balkarii (20-e gg. XX v. -nachalo XXI veka) [Gender in sociopolitical processes in KabardinoBalkaria (from 1920es - to eraly 21 century)]. Nal'chik: KBIGI. 158 p. (In Russ.)

Starodubrovskaya I.V. The crisis of the traditional North Caucasian family in the post-Soviet period and its consequences. Journal of Social Policy Studies, 17(1), 39-56 (in Russ.). doi: 10.17323/727-0634-2019-17-1-39-56

Tönnies F. (2002). Obshchnost' i obshchestvo: osnovnye ponjatija chistoj socilogii

[Gemeinschaft und Gesellschaft. Grundbegriffe der reinen Soziologie. Russian translation]. Moscow: Vladimir Dal'.

Zakharov S.V. (Ed.) (2018). Russia's population in 2016: $24^{\text {th }}$ Annual Demographic Report. Moscow: HSE publishing house. 448 p. (In Russ.)

\section{ПРИЛОЖЕНИЕ}

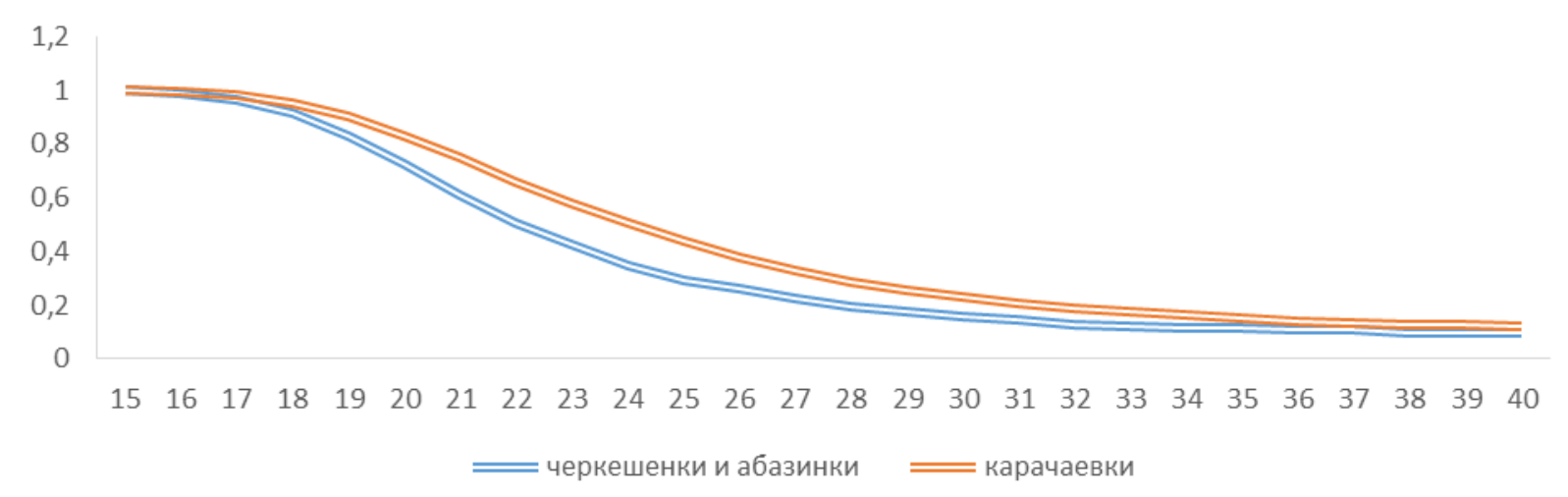

Рисунок П1. Кумулятивная вероятность «дожития» бездетной, карачаевки, черкешенки и абазинки 1950-54 годов рождения

Источник: Данные ВПН-2010.

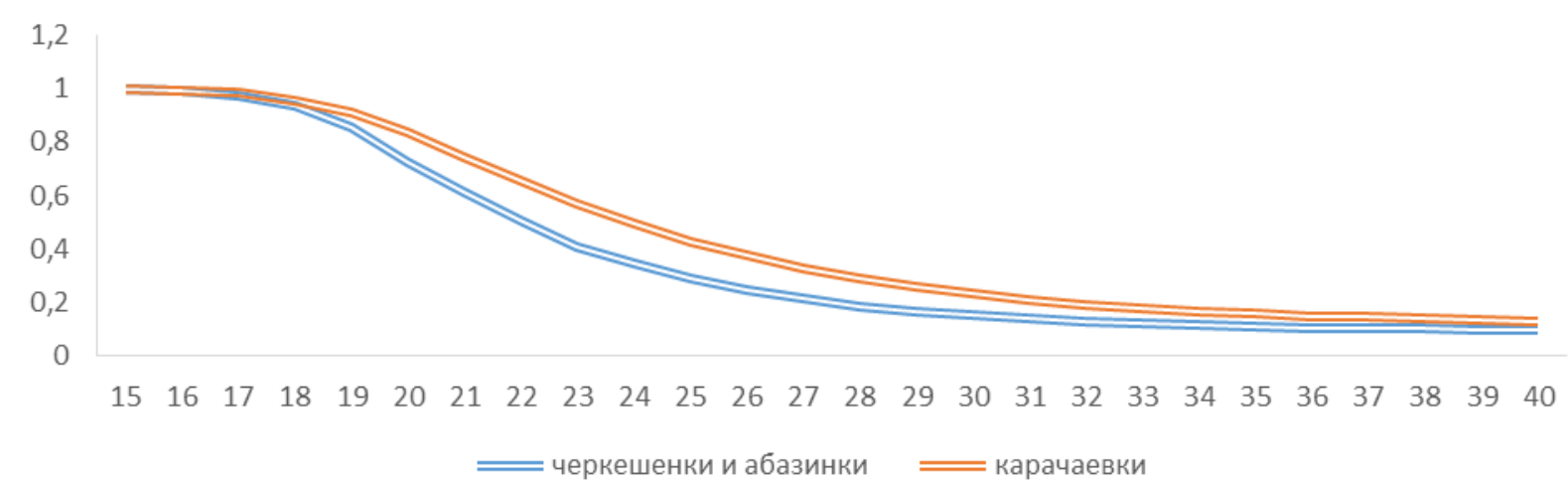

Рисунок П2. Кумулятивная вероятность «дожития» бездетной, карачаевки, черкешенки и абазинки 1955-59 годов рождения

Источник: Данные ВПН-2010. 


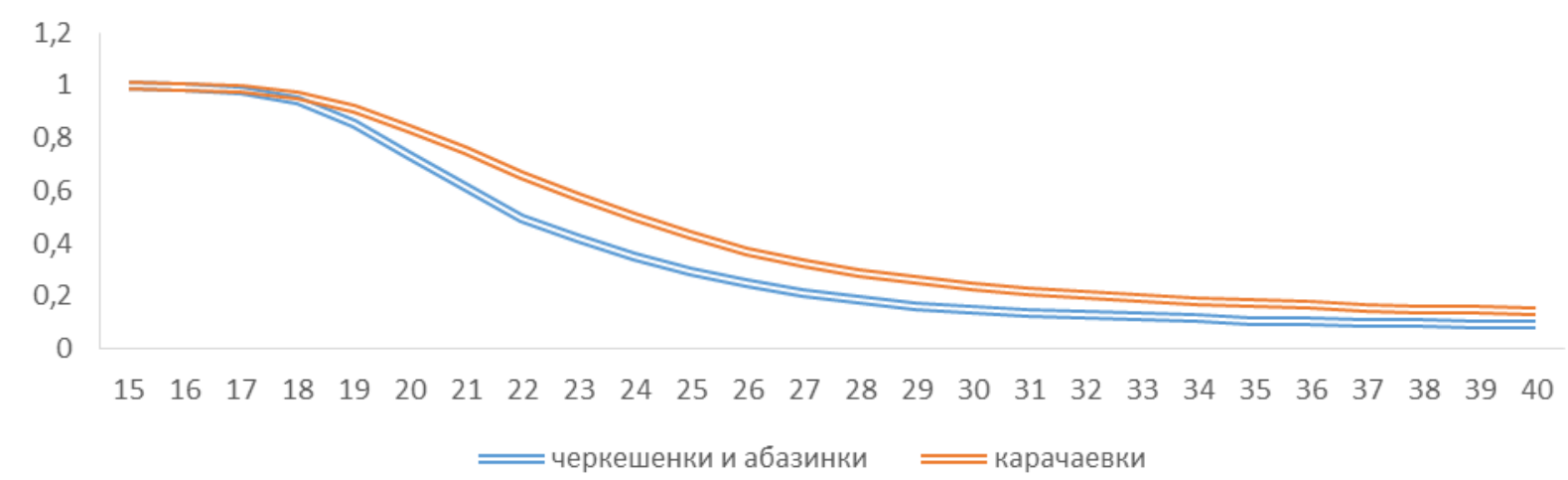

Рисунок ПЗ. Кумулятивная вероятность «дожития» бездетной, карачаевки, черкешенки и абазинки 1960-64 годов рождения

Источник: Данные ВПН-2010.

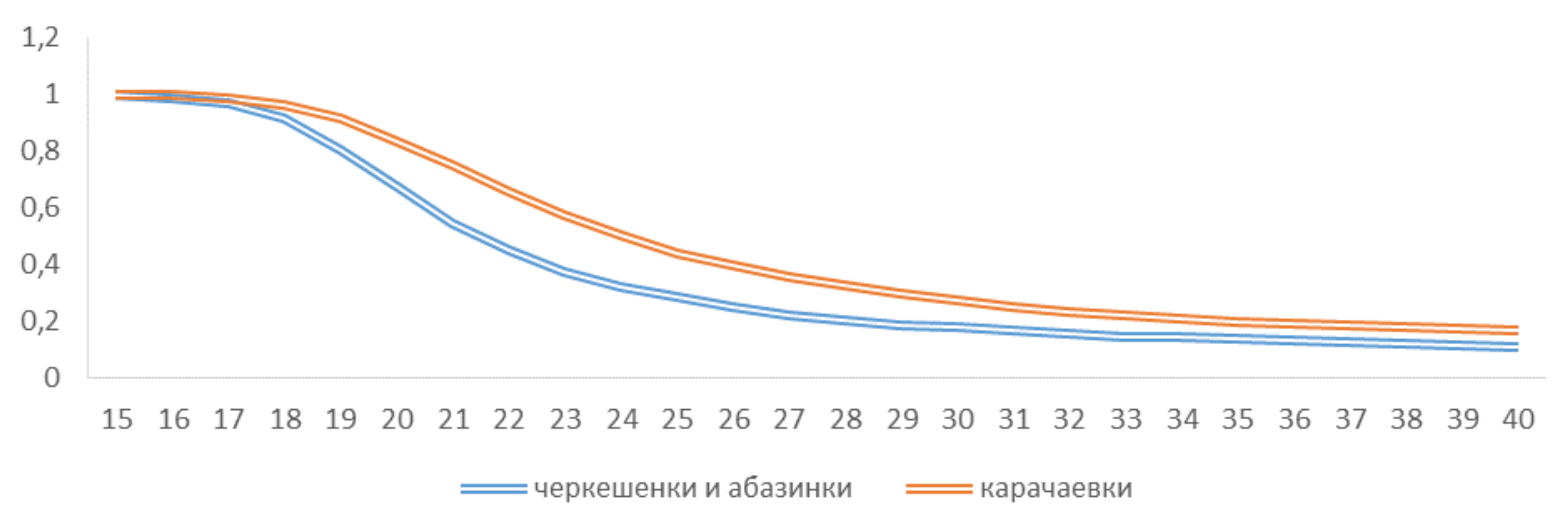

Рисунок П4. Кумулятивная вероятность «дожития» бездетной, карачаевки, черкешенки и абазинки 1965-69 годов рождения

Источник: Данные ВПН-2010.

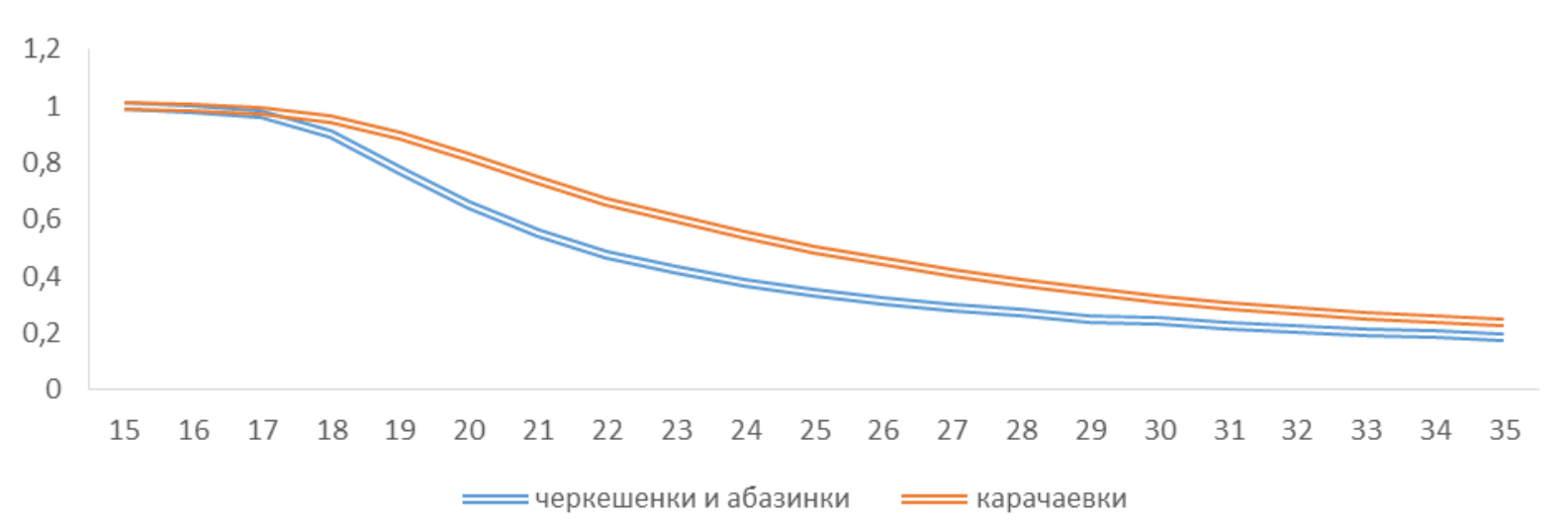

Рисунок П5. Кумулятивная вероятность «дожития» бездетной, карачаевки, черкешенки и абазинки 1970-74 годов рождения

Источник: Данные ВПН-2010. 


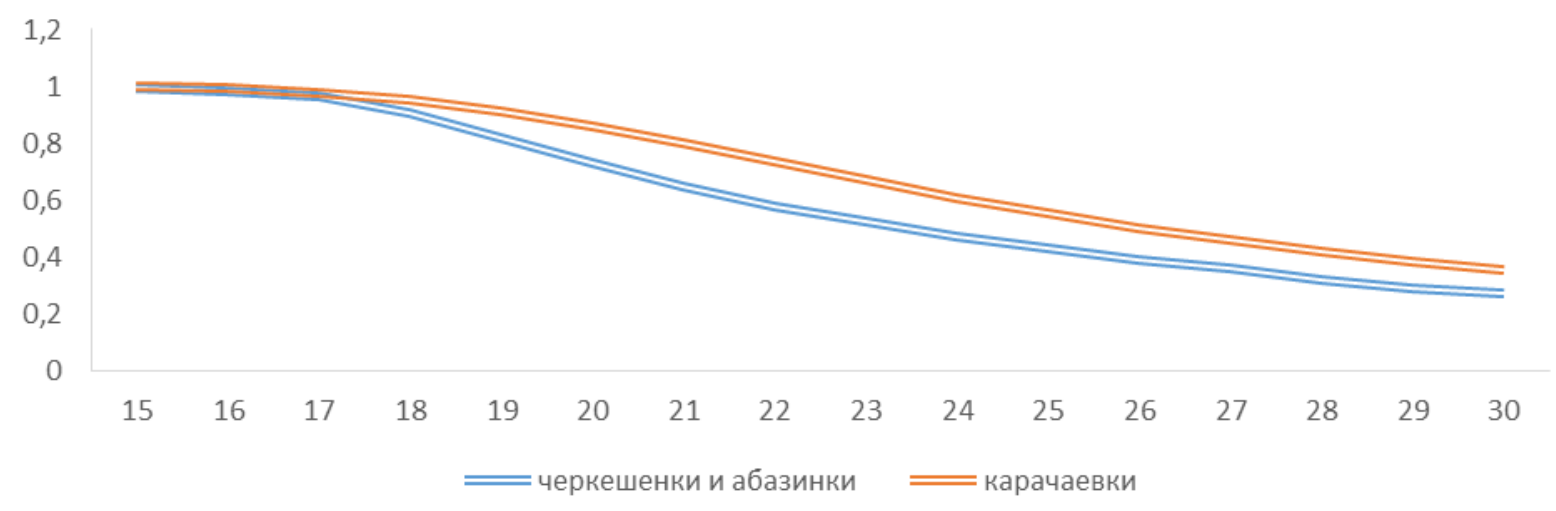

Рисунок Пб. Кумулятивная вероятность «дожития» бездетной, карачаевки, черкешенки и абазинки 1975-79 годов рождения

Источник: Данные ВПН-2010.

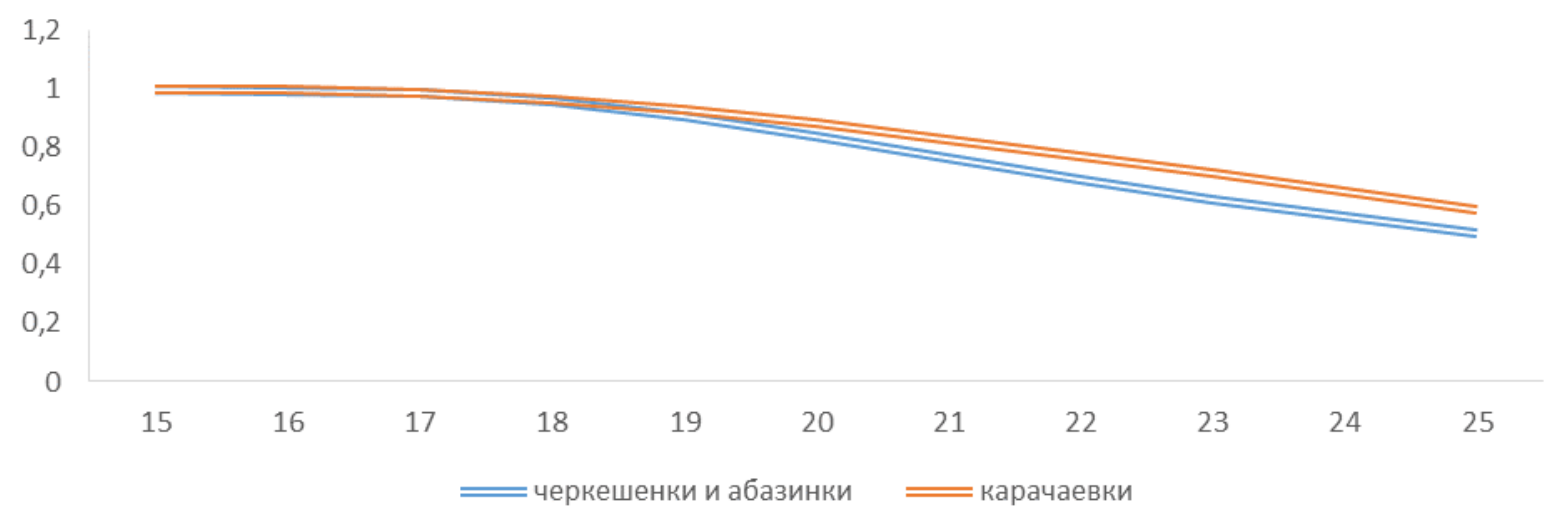

Рисунок П7. Кумулятивная вероятность «дожития» бездетной, карачаевки, черкешенки и абазинки 1980-84 годов рождения

Источник: Данные ВПН-2010. 